\title{
The changing role of Guanxi in influencing the development of entrepreneurial companies : a case study of the emergence of pharmaceutical companies in China
}

\author{
Citation for published version (APA): \\ Peng, H., Duysters, G. M., \& Sadowski, B. M. (2016). The changing role of Guanxi in influencing the \\ development of entrepreneurial companies : a case study of the emergence of pharmaceutical companies in \\ China. International Entrepreneurship and Management Journal, 12(1), 215-258. https://doi.org/10.1007/s11365- \\ 014-0323-6
}

DOI:

10.1007/s11365-014-0323-6

Document status and date:

Published: 01/01/2016

\section{Document Version:}

Accepted manuscript including changes made at the peer-review stage

\section{Please check the document version of this publication:}

- A submitted manuscript is the version of the article upon submission and before peer-review. There can be important differences between the submitted version and the official published version of record. People interested in the research are advised to contact the author for the final version of the publication, or visit the $\mathrm{DOI}$ to the publisher's website.

- The final author version and the galley proof are versions of the publication after peer review.

- The final published version features the final layout of the paper including the volume, issue and page numbers.

Link to publication

\footnotetext{
General rights

- You may freely distribute the URL identifying the publication in the public portal. follow below link for the End User Agreement:

www.tue.nl/taverne

\section{Take down policy}

If you believe that this document breaches copyright please contact us at:

openaccess@tue.nl

providing details and we will investigate your claim.
}

Copyright and moral rights for the publications made accessible in the public portal are retained by the authors and/or other copyright owners and it is a condition of accessing publications that users recognise and abide by the legal requirements associated with these rights.

- Users may download and print one copy of any publication from the public portal for the purpose of private study or research.

- You may not further distribute the material or use it for any profit-making activity or commercial gain

If the publication is distributed under the terms of Article 25fa of the Dutch Copyright Act, indicated by the "Taverne" license above, please 


\title{
The changing role of guanxi in influencing the development of entrepreneurial companies: a case study of the emergence of pharmaceutical companies in China
}

\author{
Huatao Peng • Geert Duysters • Bert Sadowski
}

(C) Springer Science+Business Media New York 2014

\begin{abstract}
Guanxi" is a term in Chinese referring to the reciprocal nature of interpersonal relationships. Its attributes, which are specific to Chinese culture, have been the focus of recent literature. Whereas the impact of guanxi seems to be quite similar to that of general relationships, ties or connections, it is characterized by a number of different dimensions. In this paper, we studied 44 entrepreneurial companies in the pharmaceutical industry in China to examine these attributes in greater detail. We use a system dynamics model to simulate the influence of various guanxi variables - the strength, scale and structure of guanxi - on the development of entrepreneurial companies.
\end{abstract}

Keywords Guanxi · Entrepreneurial companies · System dynamics · Network evolution

\section{Introduction}

According to the Global Entrepreneurship Monitor (GEM) project, entrepreneurial activities in China are the second-most prolific in the Asia Pacific/South Asia region. In fact, China is regarded as one of the most active countries in the world in the area of entrepreneurship (Xavier et al. 2013). The 2012 GEM Global Report also pointed out

\footnotetext{
H. Peng $(\bowtie)$

School of Management, Wuhan University of Technology, 122 Luoshi Road Hongshan District, Wuhan 430070, People's Republic of China

e-mail: penghuatao@126.com

G. Duysters

Department of Organization and Strategy, Tilburg School of Economics and Management, Tilburg University, P.O. Box 90153, 5000 LE Tilburg, The Netherlands

e-mail: gduysters@uvt.nl

B. Sadowski

School of Innovation Sciences, Eindhoven University of Technology, Den Dolech 2,

5612AZ Eindhoven, The Netherlands

e-mail: b.m.sadowski@tue.nl
} 
that entrepreneurial activities in China are characterized by a classic form of opportunity entrepreneurship. Personal networks represent an effective means for Chinese entrepreneurial companies to find and exploit potential opportunities (Kreiser et al. 2013; Patel and Terjesen 2011; Semrau and Werner 2013; Arregle et al. 2013). The Chinese have a word, "guanxi", for these networks and the nature of the interpersonal relationships involved. The characteristics of these personal networks are the very reason guanxi has been such a necessary and important factor of production in the Chinese economy. A growing number of studies have shown that it is unavoidable for Chinese companies' entrepreneurial activities to be imbedded in a guanxi network (Park and Luo 2001; Yeung and Tung 1996; Yu et al. 2013; Guo and Miller 2010; Liao and Sohmen 2001; Yang and Jiang 2010; Arribas et al. 2012; Puffer et al. 2010; Lovett et al. 1999; Yang and Wang 2011).

Prior studies have already shown that guanxi, which plays a long-term role in the sustainable development of entrepreneurial companies, always co-evolves with them (Yu et al. 2013; Troilo and Zhang 2012). However, within the growing literature on entrepreneurial companies' guanxi, many different conclusions have been drawn some of them at complete odds - with regard to its impact on company survival and development (Semrau and Werner 2013). With regard to the question of what form of guanxi is most useful and valuable for the development of entrepreneurial companies, answers range from weak ties (Davidsson and Honig 2003) to strong ties (McNally 2011) or even mixed ties (Kotha and George 2012). As for what kind of guanxi structure is most effective, answers include compact structure (Alcott and Christopoulos 2011), loose structure (Walker et al. 1997) or comprehensive structure (Liao and Welsch 2003). And finally, the right answers to the question of how many guanxi are actually effective for the development of entrepreneurial companies probably include both limited scale (Parker 2008) and limitless scale (Haggerty and Haggerty 2011). It is therefore obvious that the role of guanxi in influencing development is complicated. In addition to questions about the development of entrepreneurial companies in certain industries, a number of other questions remain unanswered, such as: What are the changing rules for various attributes of entrepreneurial companies' guanxi? How do these guanxi attributes create value specifically in terms of company development? To examine these issues, we need to make some specific clarifications and create new models to fit the Chinese context.

As a matter of fact, the entrepreneurial companies' guanxi comprises comprehensive attributes, including strength, scale and structure. These attributes influence one another during the companies' development. By applying a dynamic view, along with social network theory and entrepreneurship management theory, this paper focuses on the role of guanxi in creating value during development from the point of view of its comprehensive attributes. This paper examines a group of entrepreneurial companies in the pharmaceutical industry in China from 1953 to 2012. It studies the changing rules of guanxi by examining the data generated from a questionnaire survey and modeling their development with system dynamics models. As opposed to similar research in the area, this paper is dedicated to measuring the guanxi in terms of its comprehensive attributes. It focuses on outlining the cross-effects of the guanxi attributes, simulating the overall influence of guanxi on entrepreneurial companies' development.

The article is organized as follows. "Theoretical background" section provides a review of the literature and our hypotheses. "Strength of the guanxi" section is devoted 
to describing the data and method. We present a dynamic feedback model of the coevolution of entrepreneurial companies' guanxi attributes and development in "Scale of the guanxi" section. And finally, we summarize our results.

\section{Theoretical background}

In China, guanxi is influenced and nurtured by Confucian culture and ideas (Gibb and Li 2003; Liao and Sohmen 2001; Park and Luo 2001), embodied as "networks of informal relationships and exchanges of favors" (Lovett et al. 1999) and formed on the basis of "quanzi" (which also means "circle" or "cycle"), trust, dependency, responsibility, assurance, favors and understanding, thus possessing ethical and other attributes (Theingi and Phungphol 2008). Although the importance of guanxi is debatable (Liao and Sohmen 2001; Yu et al. 2013), most researchers agree that its evolution has played a crucial role in the development and expansion of entrepreneurial companies since it creates positive value for those companies. Guanxi can guide entrepreneurial companies in terms of: choosing suitable partners, obtaining useful information and complementary resources and capabilities (Pun et al. 2000; Park and Luo 2001), recognizing entrepreneurial opportunities, accurately positioning themselves with regards to the needs of market development (Sheng et al. 2011), and reducing uncertainty and risk in an unstable institutional environment (Puffer et al. 2010; Liao and Sohmen 2001; Park and Luo 2001). Moreover, guanxi also serves as a governance function, which can reduce the negative influence on firm performance exerted by factors such as weak market-supporting institutions, the absence or imperfection of contractual property rights agreements and so on ( $\mathrm{Li}$ and Sheng 2011; Boso et al. 2013).

\section{Strength of the guanxi}

The academic literature has not reached agreement on how strong guanxi should be or what kind of guanxi strength is most valuable during an entrepreneurial company's development. For example, Leung et al. (2006) propose that during their development process, entrepreneurial companies should establish strong ties as much as possible and prioritize those ties, since this means for them to find and hire high-level talent with common values and objectives. But this argument has been questioned in the literature. Zolin et al. (2011), for instance, found that entrepreneurial teams formed with wellknown acquaintances (which would indicate strong ties) are helpful for the initiators in terms of formulating the work roles within entrepreneurial teams but not conducive to dismissing team members when necessary. Strong ties may therefore both increase and decrease human resource flexibility.

In their investigation of 241 companies in China, Sheng et al. (2011) found that when market demand is uncertain or technological turbulence is high, the guanxi established with government officials cannot create value for entrepreneurial companies. This result, too, has been called into doubt, however. Boso et al. (2013) proposed that entrepreneurial companies should build strong ties with government agencies and managers in other business organizations to help them achieve greater profits through both entrepreneurial and market-oriented efforts. It is thus evident that whether or not 
strong guanxi will positively influence the development of entrepreneurial companies, success is ambiguous and decided by various factors.

\section{Scale of the guanxi}

The scale of the guanxi is represented by an index indicating the range of connections a party has through guanxi (Puffer et al. 2010), as defined by the number of direct links an entrepreneur or entrepreneurial company has with other agents (Arribas et al. 2012). There is no agreement, as yet, in the academic literature on how a large range or scale of guanxi can better create value for entrepreneurial companies, since their choices about network scale are influenced by a number of factors, such as business type (Troilo and Zhang 2012; Arribas et al. 2012), organizational characteristics (e.g., strategic capabilities and orientation, size and history) (Xin and Pearce 1996), level of influence of network members and so on (Yu et al. 2013). Under normal circumstances, guanxi mainly existed in in-groups, but as time went by, it gradually expanded to out-groups (Puffer et al. 2010), during the process of which the guanxi networks of entrepreneurial companies gradually transferred from personal networks to business networks at the firm and market level. If the guanxi network of an entrepreneurial company is only limited to personal guanxi, in most cases that company can only use existing knowledge and familiar methods to carry out its business activities. This obviously cannot meet the requirements of a complex entrepreneurial environment, thus impacting the entrepreneurial company's dynamic abilities (Peng 2003; Sheng et al. 2011; Hite and Hesterly 2001; Adler and Kwon 2002). Against such a background, therefore, the scale of guanxi must be continuously expanded so as to obtain access to a variety of resources and thereby satisfy the dynamic need for resources (Semrau and Werner 2013).

\section{Structure of the guanxi}

As early as the 6th century A.D. in China, Confucius had divided authority into different hierarchical structures. In interpersonal communications, family members are placed within a core level of guanxi, but relatives, classmates, colleagues, friends and acquaintances exist in a more distant layer, since the levels of trust vary (Park and Luo 2001). Guanxi, one of the major attributes of Chinese social networks, is also derived from various other types of relationship, including social, hierarchical and market relationships (Theingi and Phungphol 2008). The structure of the guanxi also helps determine the overall guanxi status, related as it is to the emotional hierarchy, which includes the hierarchy in "renqing" 1 and overall acceptance level (Yang and Jiang 2010). In our case, the renqing hierarchy mainly refers to the importance of past relationships with relatives, friends, colleagues, acquaintances and so forth, and the acceptance level reflects the degree of mutual recognition decided by the cultural and behavioral mode of guanxi. Similar to the viewpoint held in the field of sociology,

\footnotetext{
"Renqing consists not of the exchange of equal value in a market economy but in "Kula Ring" among social behavioral exchange. Renqing is the accumulation of unpaid debts emanating from guanxi (Chen 2011).
} 
Arribas et al. (2012) assume that the structure of the guanxi of entrepreneurs is not distributed randomly but rather has certain preferences. A compact or close-degree structure has already become one of the evaluative indexes for entrepreneurial companies' guanxi structure, which can reflect the maturity of the guanxi partnership (Yang and Jiang 2010).

\section{Hypotheses}

Guanxi strength and entrepreneurial companies' development

When the guanxi of an entrepreneurial company stems from strong ties, it may trigger unethical conduct that can negatively impact the company (Yu et al. 2013). In fact, any guanxi can bolster or damage a firm's profitability (Gibb and Li 2003; Pitt et al. 2006) and "network ties are critical in explaining variations in performance outcomes of strategic orientation activities in a less developed market" (Boso et al. 2013). When there are rent-seeking behaviors in the entrepreneurial companies' social networks, guanxi will limit the value created by the entrepreneurial companies (Minniti 2005) and even the value created by the companies' guanxi is bound to decrease. Rent-seeking behaviors often occur when there is strong guanxi. Therefore, during their development, it is necessary for entrepreneurial companies to consciously construct new guanxi in order to weaken the overall ties. As a result, the choice of guanxi with different strengths for promoting development depends on individual prerequisites, such as the companies' idiosyncratic organizational and institutional attributes (Park and Luo 2001). From the perspective of institutional theory, as legal and regulatory institutions gradually mature and business support systems gradually progress, network ties themselves become less important (Sheng et al. 2011). More specifically, after an industry becomes stable and mature and its entrepreneurial companies grow up, some network relationships are no longer important or strong (Semrau and Werner 2013). According to the analysis above, we hypothesize:

Hypothesis 1a: From a long-term perspective, the strength of entrepreneurial companies' guanxi shows a decreasing trend.

From a market expanding perspective, the management, survival and development of a company were unceasingly promoted by guanxi (Park and Luo 2001). Now, the main, and typical, opinion holds that while strong ties are more helpful to entrepreneurial companies' survival, weak ties make more contributions to entrepreneurial companies' development (Bruderl and Preisendorfre 1998; Hite and Hesterly 2001; Stearns 1996). Based on this conclusion, entrepreneurial companies should give priority to strong ties during start-up and weak ties during their growth phase. The entrepreneurial companies' development will depend more on weak guanxi and not strong guanxi. Guanxi strength is established based on mutual trust, interactions and reciprocity (Granovetter 1973). When an entrepreneurial company's guanxi evolves from being strong during the survival stage to becoming weak during the development stage, it means the degree of mutuality will be smaller, the frequency of interactions will be lower and the extent of reciprocity will be less; at that point, the corresponding 
value created by the strength of the guanxi will also decrease. In other words, guanxi becomes weaker when entrepreneurial companies entered the stable stage. In turn, weak guanxi reduces the value increment, so companies must increasingly look for other methods to become more competitive and stronger (Semrau and Werner 2013). According to the analysis above, we can hypothesize:

Hypothesis 1b: From a long-term perspective, guanxi strength positively influences the development of entrepreneurial companies.

Guanxi scale and entrepreneurial companies' development

To some extent, the relationship between entrepreneurial companies and their guanxi is a "chicken and egg question," since it is both possible that companies started their business because of abundant guanxi and that they started without much guanxi at the very beginning while expanding the scale of guanxi during their development process (Liao and Sohmen 2001). Generally speaking, the larger the scale of the guanxi, the bigger the value it can create for entrepreneurial companies, because a large local network size increases the chances of survival for the new venture (Arribas et al. 2012). Guanxi is seen as the key for entrepreneurial companies to attract resources (Semrau and Werner 2013), especially as guanxi scale of entrepreneurs has a positive impact on the growth of entrepreneurial companies (Hansen 1995). Given that the personal guanxi of an entrepreneur fails to meet the requirements of an entrepreneurial company, the guanxi of the company will no longer be confined to it. So, guanxi scale needs to be expanded (Puffer et al. 2010; Semrau and Werner 2013). In this process, the guanxi of entrepreneurial companies transfers from personal guanxi to organizational and commercial guanxi (Schulze 2007). The strategic development of entrepreneurial companies enhances their demand for resources, which in turn urges for guanxi. Related to strategic development, more guanxi shall be developed by entrepreneurial companies.

Hypothesis 2a: From a long-term perspective, guanxi scale continues to increase.

Extant theoretical and empirical research has shown that the influence of guanxi scale on entrepreneurial companies is limited. When guanxi scale reaches certain point, the newly developed guanxi probably becomes a burden for entrepreneurial companies. At this point, the marginal benefit of guanxi scale decreases. So, at this stage, entrepreneurial companies shall gradually reduce their dependence on guanxi scale to attract resources, and increasingly turn to other methods to increase their value (Semrau and Werner 2013). As a matter of fact, when entrepreneurial companies possess rich management skills or continually improve their technological skills, their need for guanxi networks becomes lower (Park and Luo 2001). It is also possible that small firms prefer to cultivate various kinds of guanxi to compensate for institutional and competitive disadvantages, while large firms lack the motivation to establish guanxi with competitive forces since they enjoy government protection (Park and Luo 2001). So, it can be concluded that the "effective guanxi scale" (the number of guanxi needed to function effectively) is not necessarily bound to expand during an entrepreneurial company's long-term development, but entrepreneurial companies must invest in a 
minimum level of guanxi (Arribas et al. 2012) and endeavor to cultivate and expand a viable guanxi network (Yeung and Tung 1996; Park and Luo 2001) when they are not sure about the optimal guanxi scale. According to the analysis above, we hypothesize:

Hypothesis 2b: From a long-term perspective, below a critical value, the development of an entrepreneurial company is positively related to guanxi scale, however above a critical value, there is no relationship with the guanxi scale.

Guanxi structure and entrepreneurial companies' development

Guanxi structure is usually established on the basis of past contacts or recommendations from acquaintances. Guanxi networks are usually manifested in multidivisional structures, as shown by Lin (1999) and Boso et al. (2013). Therefore, members engaged in guanxi of entrepreneurial companies are at different level of hierarchy and have different positions in the guanxi structure. Changes can be observed at positions and roles of members in guanxi during the development process of the company (Rosenkopf and Schilling 2007). There is some evidence showing that for nascent companies, the denser the guanxi structure, the higher possibility companies will become a success (Yang and Jiang 2010; Chen 2011). In addition, it has been proposed that the guanxi structure of companies is denser in the early development stage. When companies' guanxi structure fully develops, some members will become useless (Semrau and Werner 2013). At this stage, companies tend to have less guanxi in order to save the construction and maintenance cost of guanxi. Consequently, guanxi structure becomes sparse. Based on the argument developed above, we propose the following hypothesis:

Hypothesis 3a: From a long-term perspective, guanxi structure shows first an increasing and later a decreasing trend.

Yang and Jiang (2010) concluded that the extent of the guanxi structure exerts a positive influence on the rate of resource contribution in an entrepreneurial network, and the greater the degree of guanxi, the greater that of operational connection. Based on the position that compact guanxi works better for promoting the development of entrepreneurial companies, Park and Luo (2001) further suggest that, as a kind of loosely structured network, guanxi can efficiently facilitate economic exchanges and overcome the drawbacks of administrative intervention from the Chinese government. Compact network structure always corresponds to strong network ties, and loose network structure corresponds to weak network ties (Granovetter 1973, 1985). It's true in the case of guanxi networks, and network closure represents strong ties in the network (Kreiser 2011). When more and more guanxi members try to enter into the entrepreneurial companies' relatively small network structure, network closure will obviously increase and this will help the entrepreneurial companies' development. At the same time, when the guanxi structure reaches a certain scale, some guanxi members become redundant (Semrau and Werner 2013). Then the proportion of strong ties will decrease and the function of the entire guanxi structure for the entrepreneurial companies will also decay. According to the analysis above, we suggest: 
Hypothesis 3b: From a long-term perspective, the influence of guanxi structure on the development of entrepreneurial companies shows a U-shaped trend.

Data and methodology

\section{Sample and data collection}

In this study, we focus on a sample of Chinese firms, active in the pharmaceutical industry. Compared with the effect of guanxi in some other industries or countries, the Chinese pharmaceutical industry has its own characteristics in terms of strength, scale and structure attributes (Orsenigo et al. 2001; Powell 1996; Powell et al. 1996; Staropoli 1998). The pharmaceutical industry contains numerous actors and these actors all have complex guanxi between them, thus dictating the formation and evolution of the guanxi networks (Wang et al. 2009). Based on a typical pharmaceutical supply chain, the members in the companies' guanxi include: primary manufacturing companies, secondary manufacturing companies, market warehouse/distribution centers, wholesalers, retailers/hospitals and patients (Shah 2004).

Our samples of entrepreneurial companies in the pharmaceutical industry are taken from members of the Pharmaceutical Association in Hubei Province, China, and the main entrepreneurial companies supported by Hubei $S$ \& $T$ Bureau (as listed in Appendix 1). These two institutions helped us complete the questionnaire survey. For this study, we only selected entrepreneurial companies in existence for more than 10 years that have formed stable guanxi networks. The respondents therefore had more experience with and awareness of guanxi, which enabled us to analyze changes that had taken place during the period from their start-up through to present-day. These companies represent the most comprehensive information available on the progress of entrepreneurship and growth in the pharmaceutical industry. One of the key advantages of our sample is that these are all typical entrepreneurial companies and their guanxi management has proven to be effective and successful.

The biggest difficulty of the system dynamics model is checking the scientific formulas and obtaining reasonable data (Freeman et al. 2011). We combined the mainstream concepts from prior studies so as to accurately acquire the basic data for the parameters in our system dynamics model (as shown in Appendix 2). After the questionnaire was handed out, we held a consultation meeting for the purpose of collecting data by interviewing presidents, marketing managers or customer managers from each pharmaceutical company, who were invited because they were considered to have more experience with, better recognition of and deeper insight into the companies' guanxi.

One pharmaceutical company will often have a wide range of products and various guanxi members. To simplify the question, we mainly studied the guanxi in the pharmaceutical companies' core product sector, which included hospitals, pharmacies and other institutions that interact with patients directly. In addition, we defined the meaning of guanxi strength, guanxi scale, guanxi structure and guanxi value for the entrepreneurial companies in the pharmaceutical industry and explained them to the respondents.

We derived our observed items from the literature review, but to confirm our basic judgments and find out whether they fit the reality of entrepreneurial companies in the 
pharmaceutical industry, we needed the opinions of actual entrepreneurs. Participants were given about $30 \mathrm{~min}$ to complete a semi-open questionnaire. The participants had to fill in the questionnaire independently which is very useful for setting up equations. This process was divided into two steps. The first step involved selecting 17 entrepreneurial companies to answer the questions. Then we made an initial simulation. The results from the pharmaceutical companies confirmed that the evolution tendency can reflect the dynamic change in their social network. Based on the first step, we expanded the number of respondents and organized a new, more formal, questionnaire survey.

Some answers to the questionnaire could be obtained from customer records and financial statements. By consulting their customer records, the respondents could easily provide all the necessary information about the scale of guanxi, for example the number of network relationships and the tendency for those relationships to change with key customers and potential customers. We can also discover through this how many customers one particular customer might introduce to the company and how long a particular guanxi member cooperates with a particular company. By consulting their financial statements, the respondents could provide direct information about the value of the guanxi, such as the increased or decreased value caused by guanxi and the average value of each guanxi member. The questionnaire also contained some questions that the respondents could not answer based on their company's records but had to answer subjectively. These questions are shown in Table 1.

We sent letters of invitation for face-to-face interviews to 51 entrepreneurial companies working in the pharmaceutical industry in Hubei Province. We received 47 responses, 44 of which were satisfactory: the remaining 3 were unable to provide customer information to support their answers. The rate of effective responses is approximately $86.3 \%$. The details for the respondents are listed in Appendix 1. The descriptive statistics for all of the variables and corresponding questions are reported in Table 1.

\section{Method}

In the study, system dynamics are used as a method. The objectives of system dynamics is to build models based on computer simulation that enable us to examine in depth the interdependence, the interaction and the cause-and-effect relationships of dynamic systems (System Dynamics Society 2013). A behavioral framework was developed in order to analyze and understand the system as a whole (Zhang et al. 2013). This framework includes as building blocks a variety of flowcharts, a system of equations, and a simulation platform (Zhang et al. 2014). It is aimed at predicting future behavior of complex systems (Jeon and Shin 2014).

Throughout an entrepreneurial company's growth, the strength, scale and structure of the guanxi and its corresponding value vary greatly, with these variables all influencing one another dynamically and continuously (McNally 2011; Lechner et al. 2006). If we want to chart the evolution in the guanxi of entrepreneurial companies, we must study it from the point of dynamic simulation (Caliendo et al. 2012; Weber and Weber 2011). This paper uses the system dynamics modeling software designed by Vensim ${ }^{\mathrm{TM}}$ to build a model for doing so. With the aid of this software, with the limiting conditions designed in advance, we were able to accurately reveal the dynamic rules of 
Table 1 Descriptive statistics

\begin{tabular}{|c|c|c|c|c|}
\hline Variables & Questions & $\begin{array}{l}\text { Data } \\
\text { resources }\end{array}$ & Mean & $\mathrm{SD}$ \\
\hline Life cycle & $\begin{array}{l}\text { Based on the company's experience from } \\
\text { start-up until now, how many years at } \\
\text { best do you think your company can } \\
\text { maintain its close cooperation with } \\
\text { those important and key customers? }\end{array}$ & $\begin{array}{r}\text { Customer } \\
\text { records }\end{array}$ & 52.39 & 16.442 \\
\hline $\begin{array}{l}\text { Transformation } \\
\text { rate }\end{array}$ & $\begin{array}{l}\text { Based on the company's experience } \\
\text { from start-up until now, what } \\
\text { percentage of potential customers } \\
\text { become real customers for your } \\
\text { company? }\end{array}$ & $\begin{array}{r}\text { Customer } \\
\text { records }\end{array}$ & $26.364 \%$ & $8.3780 \%$ \\
\hline Decay rate & $\begin{array}{l}\text { Based on the company's experience } \\
\text { from start-up until now, when } \\
\text { important or key customers are no } \\
\text { longer important, what is the } \\
\text { percentage of the actual value } \\
\text { created by them to the set value? }\end{array}$ & $\begin{array}{l}\text { Financial } \\
\text { statements }\end{array}$ & $77.159 \%$ & $10.0231 \%$ \\
\hline Guanxi scale & $\begin{array}{l}\text { How many important and key customers } \\
\text { does your company have now? }\end{array}$ & $\begin{array}{r}\text { Customer } \\
\text { records }\end{array}$ & 78.86 & 144.580 \\
\hline $\begin{array}{l}\text { Value creation } \\
\text { coefficient }\end{array}$ & $\begin{array}{l}\text { Based on the company's experience } \\
\text { from start-up until now, how many } \\
\text { sales does a new key customer } \\
\text { create for your company? }\end{array}$ & $\begin{array}{l}\text { Financial } \\
\text { statements }\end{array}$ & 38.18 & 20.576 \\
\hline Guanxi structure & $\begin{array}{l}\text { What percentage of customers } \\
\text { maintain close relationships with } \\
\text { your company now? }\end{array}$ & $\begin{array}{l}\text { Subjective } \\
\text { judgment }\end{array}$ & $77.955 \%$ & $7.4956 \%$ \\
\hline $\begin{array}{l}\text { Potential } \\
\quad \text { guanxi scale }\end{array}$ & $\begin{array}{l}\text { Based on the company's experience } \\
\text { from start-up until now, from the } \\
\text { point of view of long-term } \\
\text { development in the pharmaceutical } \\
\text { industry, how many important } \\
\text { and key customers can your } \\
\text { company retain? }\end{array}$ & $\begin{array}{r}\text { Customer } \\
\text { records }\end{array}$ & 289.43 & 300.666 \\
\hline Interactions & $\begin{array}{l}\text { Using the company's experience from } \\
\text { start-up until now as your guide, } \\
\text { suppose that when your company } \\
\text { doesn't keep in touch with guanxi } \\
\text { members, the status of interactions } \\
\text { is } 0 \text {, and when it keeps in close } \\
\text { touch with them, the status of } \\
\text { interactions is } 1 . \text { Based on the status } \\
\text { quo for your company, how many } \\
\text { customers does your company have } \\
\text { when there is almost no contact? } \\
\text { How many when the status of } \\
\text { interaction is } 0.8 ?\end{array}$ & $\begin{array}{l}\text { Subjective } \\
\text { judgment }\end{array}$ & $\begin{array}{l}285.68 \\
162.95\end{array}$ & $\begin{array}{r}147.197 \\
92.801\end{array}$ \\
\hline Mutual trust & $\begin{array}{l}\text { Using the company's experience from } \\
\text { start-up until now as your guide, } \\
\text { suppose the worst level of the trust } \\
\text { between your company and one of its } \\
\text { key customers is } 0 \text { and the best level is } 1 \text {. } \\
\text { Based on the status quo for }\end{array}$ & $\begin{array}{l}\text { Subjective } \\
\text { judgment }\end{array}$ & $70.682 \%$ & $11.8905 \%$ \\
\hline
\end{tabular}


Table 1 (continued)

\begin{tabular}{|c|c|c|c|c|}
\hline Variables & Questions & $\begin{array}{l}\text { Data } \\
\text { resources }\end{array}$ & Mean & SD \\
\hline \multirow{3}{*}{ Reciprocity } & $\begin{array}{l}\text { your company, what is the percentage of } \\
\text { customers in close contact with your } \\
\text { company for whom you believe the level } \\
\text { of trust approaches } 0.8 ?\end{array}$ & & & \\
\hline & \multirow[b]{2}{*}{$\begin{array}{l}\text { Using the company's experience from } \\
\text { start-up until now as your guide, } \\
\text { suppose the lowest degree of } \\
\text { reciprocity is } 0 \text { and the highest } \\
\text { is } 1 \text {. Based on the status quo for } \\
\text { your company, how many sales } \\
\text { do the customers create for your } \\
\text { company when the degree of } \\
\text { reciprocity approaches } 1 \text { versus } \\
\text { when it is } 0.8 ?\end{array}$} & \multirow{2}{*}{$\begin{array}{l}\text { Subjective } \\
\text { judgment }\end{array}$} & 2154.55 & 2145.244 \\
\hline & & & 1663.64 & 1513.212 \\
\hline $\begin{array}{l}\text { Sales based } \\
\text { on guanxi }\end{array}$ & $\begin{array}{l}\text { How many sales do the important } \\
\text { and key customers create for } \\
\text { your company now? }\end{array}$ & $\begin{array}{l}\text { Financial } \\
\text { statements }\end{array}$ & 372.73 & 322.139 \\
\hline
\end{tabular}

guanxi in influencing the development of entrepreneurial companies through system simulation. As there is some tradition in using system dynamics based on Vensim ${ }^{\mathrm{TM}}$ to explore factors explaining the development of complex systems (Eberlein and Peterson 1992), this software has been used to study the dynamic rules of guanxi.

We followed the research design (outlined below in Fig. 1) which put a great level of emphasis on expert opinions gathered from industry participants (see left part of the figure "Consultation meeting") and was aimed at verifying assumptions in the model based on survey results among these participants (see "questionnaire"). The findings from the literature have been used to design a questionnaire, which allowed us to design

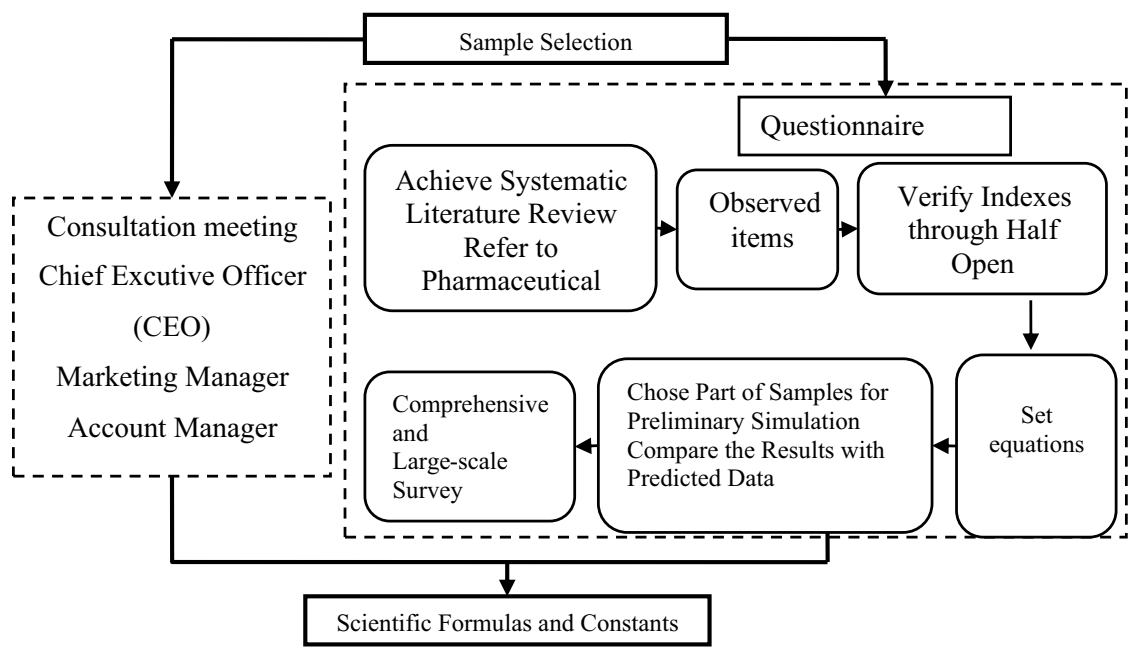

Fig. 1 The process to obtain scientific formulas and constants 
the systems model, to introduce the appropriate formulas and to adjust the parameters in the model. The flowchart provides an overview on how the sample and the variables were selected. In addition, it provides insights to the extent we used for the design of the model information gained from the questionnaire research. This allowed us to show that the selection of the variables and questionnaire design can be considered as appropriate and produce valid results.

\section{A dynamic feedback model of the evolution of guanxi in entrepreneurial companies' development}

The pharmaceutical industry is always in dynamic evolution because the conditions of opportunity and advantages of emerging pharmaceutical ventures influence the nature of pharmaceutical R \& D activities, organizational capabilities and patterns of industry evolution (Galambos and Sturchio 1996; Henderson et al. 1999). At the same time, collaborative networks among pharmaceutical firms and other institutions always evolve with industrial innovation activities. In order to dynamically study the role of guanxi in influencing the development of entrepreneurial companies in the pharmaceutical industry in China, we focused specifically on hospitals and drug stores. In our models, all of the variables pertaining to the attributes of guanxi, including strength, scale and structure, are embodied as different attributes of the entrepreneurial pharmaceutical companies' guanxi with hospitals and drug stores. Most models for entrepreneurial firms start from the assumption that firm evolution is related to the learning processes within the firm and active interaction with its environment (Schutjens and Stam 2003). The evolution of entrepreneurial companies' guanxi has a similar learning effect and is determined by the comprehensive interaction of guanxi attributes.

As entrepreneurial companies develop, the attributes of guanxi, such as strength, $A_{\text {strength }}(t)$, scale, $L_{\text {scale }}(t)$, and structure, $L_{\text {structure }}(t)$, will change accordingly (McNally 2011; Yu et al. 2013; Wang et al. 2009; Orsenigo et al. 2001). They interact with one another and ultimately determine the sales derived from guanxi, $L_{\text {sales }}(t)$, and the impact guanxi has on the survival and development of the entrepreneurial companies. Scholars have not reached consensus as to whether strong or weak ties play a greater role, but they generally recognize that the degrees of strong or weak ties are affected by mutual trust (Semrau and Werner 2013), interactions (Lee and Tsang, 2001; Kreiser et al. 2013) and reciprocity (Lockett et al. 2006), which are indicated in the model as a mutual trust factor, $A_{\text {trust }}(t)$, an interactions factor, $A_{\text {interactions }}(t)$, and a reciprocity factor, $A_{\text {reciprocity }}(t)$, respectively. Therefore, we get the formula:

$$
A_{\text {strength }}(t)=A_{\text {trust }}(t) * A_{\text {interaction }}(t) * A_{\text {reciprocity }}(t)
$$

Mutual trust represents the degrees of constant, transmittable and tacit trust between each agent when an entrepreneurial company and its guanxi members engage in credible, strong and extensive commitment (Kreiser et al 2013). As long as the guanxi members remain close, to a certain degree, to the entrepreneurial company and in the core layer of the company's guanxi network (it's an ideal state), then they can trust one another (Semrau and Werner 2013). But when the guanxi members are farther away 
from the entrepreneurial company and there are fewer and fewer members in that core layer, the mutual trust factor also decreases. According to the critical conditions, we get:

$$
A_{\text {trust }}=(0,0)(1,1)
$$

Interactions represent the effects the entrepreneurial companies' guanxi structure has on the frequency of formal or informal association and on the contact between the internal individuals of the companies' guanxi members (Park and Luo 2001). When the range or scale of the entrepreneurial companies' guanxi network is very small, they communicate with each other often (Zolin et al. 2011). But when the guanxi scale expands rapidly and the needs and behavior characteristics become more various and complicated, then the frequency of communication decreases and the mutual trust factor will be lower. More particularly, when the guanxi scale expands to a certain number, $c_{\text {scale }}$, the interaction factor goes to 0 . According to the critical conditions, we get:

$$
A_{\text {interaction }}=(0,1)\left(c_{\text {range }}, 0\right)
$$

Reciprocity represents the benefits that both entrepreneurial companies and their guanxi members can earn from the guanxi network (Caliendo et al. 2012). For the guanxi members, when the mutual return from the guanxi network increases to a certain number, $c_{\text {value }}$, the reciprocity factor becomes 1 . According to the critical conditions, we get:

$$
A_{\text {reciprocity }}=(0,0)\left(c_{\text {value }}, 1\right)
$$

When strong ties reach a certain degree, or the strong ties take priority in the guanxi network, with possibly a maximum number, $c_{\text {potential, }}$ there is a certain barrier to entering the guanxi network and the potential guanxi scale, $A_{\text {potential }}$, is relatively smaller. On the other hand, it is relatively easier to enter the guanxi network, which means entry, $R_{\text {entry }}$ into the guanxi network will increase and the potential network scale is bigger (Granovetter 1985; Kreiser et al. 2013). From the questionnaire survey, we get:

$$
A_{\text {potential }}=c_{\text {potential }} /\left(1-A_{\text {relationship }}(t)\right)
$$

As entrepreneurial companies continue to grow, the differences in the guanxi members' level of learning, growth and adaptability will also lead to differences in the companies' life cycle, $C_{\text {lifecycle }}$, (Haggerty and Haggerty 2011; Batjargal and Liu 2002). The reliance on guanxi will therefore fade (McNally 2011) and some guanxi members will leave or be eliminated from the entrepreneurial companies' core guanxi network (Cantner and Graf 2006; Haggerty and Haggerty 2011), which is indicated by the exit factor, $R_{\text {exit }}$. Therefore, we get:

$$
R_{\text {exit }}(t)=L_{\text {scale }}(t) / C_{\text {lifecycle }}
$$

The increment of guanxi scale that is converted into an entrepreneurial company's guanxi network will derive from the potential social network (Evald and Bager 2008; Chen 2011). But not all potential guanxi members can become actual ones with a 
positive relevant relationship to the transformation rate, $C_{\text {transformation }}$ Therefore, we get:

$$
R_{\text {entry }}(t)=A_{\text {potential }}(t) C_{\text {transformation }}
$$

During entrepreneurial companies' development, many new members join, while some leave (Parker, 2008). Therefore, it's obvious that:

$$
L_{\text {scale }}(t)=L_{\text {scale }}(t)(t-\Delta t)+\Delta t\left(R_{\text {enter }}(t-\Delta t)-R_{\text {withdraw }}(t-\Delta t)\right)
$$

The increment of structure compactness in an entrepreneurial company's guanxi network (indicated by the "clustering coefficient" $R_{\text {clustering }}$ ) is mainly affected by the distribution density of newly added members in the guanxi's current and potential scale (Casciaro 1998). The scale of current guanxi members needs to take into account how effective members are, because some guanxi members lose their original value (indicated by the decay rate, $C_{\text {decay }}$ ), which makes the effective guanxi scale gradually shrink. Therefore we get:

$$
R_{\text {clustering }}(t)=R_{\text {entry }}(t) /\left(R_{\text {entry }}(t)+\left(L_{\text {scale }}(t) C_{\text {decay }}\right)\right.
$$

The degree of guanxi strength also has a negative effect on entrepreneurial companies' guanxi structure, which results in distant ties and a loose degree of guanxi structure, $R_{\text {loose }}$ (Karra et al. 2006). The more weak ties or structural holes there are in an entrepreneurial company's guanxi network, the more scattered and looser its guanxi distribution will be (Granovetter 1985; Pitt et al. 2006). There is some agreement in the literature that weak ties correspond to loose structures. Therefore we get:

$$
R_{\text {loose }}(t)=L_{\text {structure }}(t)\left(1-\mathrm{A}_{\text {relationship }}\right)
$$

During an entrepreneurial company's development, many members will enter into the core layer of the company's guanxi network, making the guanxi structure more compact (Fuller and Warren 2006), while others will be eliminated from the core layer, making the guanxi structure looser. Therefore, it's obvious that:

$$
L_{\text {structure }}(t)=L_{\text {structure }}(t)(t-\Delta t)+\Delta t\left(R_{\text {clustering }}(t-\Delta t)-R_{\text {loose }}(t-\Delta t)\right)
$$

As one of the important intangible capitals of entrepreneurial companies, guanxi can create value that cannot be replaced by economic capital. The newly added guanxi value of entrepreneurial companies (indicated by "average profit growth", $R_{\text {profit }}$ ) is determined by the increment of effective guanxi scale and the value-creation ability of an entrepreneurial company's guanxi network (Lerner et al. 1997; Lechner et al. 2006) (as indicated by the "value creation coefficient" $C_{\text {creation }}$ ). Therefore we get:

$$
R_{\text {profit }}(t)=R_{\text {entry }}(t) C_{\text {creation }}
$$

When certain functions and attributes no longer satisfy the constantly changing demands of the entrepreneurial companies, their value will weaken. This may even lead to a decrease in the value of the guanxi for the entrepreneurial companies or possibly negative values (Ferriani et al. 2009), since entrepreneurial companies must still sustain 
the corresponding costs, $R_{\cos t}$ (Arregle et al. 2013), such as entertainment and giftgiving expenditures (Du et al. 2013). Therefore we get:

$$
R_{\cos t}(t)=L_{\text {structure }}(t) C_{\text {decay }}
$$

We have drawn a dynamics flowchart based on the above analysis to show the logical relationships between guanxi strength, guanxi scale, guanxi structure and guanxi value during entrepreneurial companies' development (Fig. 2).

As can be seen in Fig. 2, a variety of variables are included in the model: three level variables, six rate variables and five auxiliary variables (the details on these variables are shown in Appendix 2). In the study, we focus specifically on dynamic rules of guanxi strength, guanxi scale and guanxi structure of entrepreneurial companies. In addition, the dynamic relationships with sales based on guanxi are examined in greater detail. .

\section{Findings}

The time horizon for this model is from the beginning of the companies' entrepreneurial efforts to year 2030 and the simulation step is 0.5 years. Since the respondents were obviously established in different years and also started with entrepreneurship at different times, we designated 2013 as the base year for the simulation study. The constants in this model are the empirical values from the beginning of entrepreneurship to the end of 2012, which are shown in Table 1. With this model, we were able to simulate evolutionary patterns in the guanxi of entrepreneurial companies operating in the pharmaceutical industry.

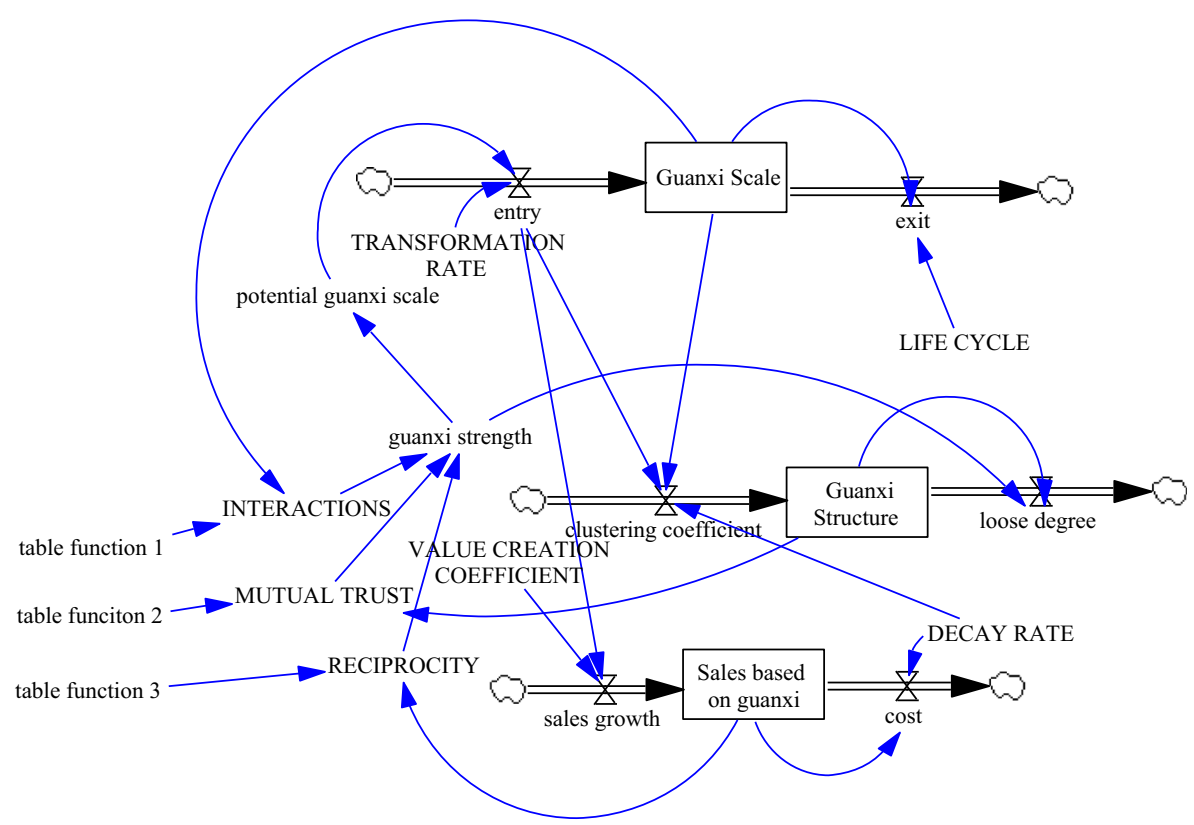

Fig. 2 System dynamics flowchart of guanxi and entrepreneurial companies' development 
Changes in the strength of the guanxi and its influence on entrepreneurial companies' development

The results of the system dynamics simulation (as shown in Fig. 3) reveal that during entrepreneurial companies' development, the strength of their guanxi decreases to a point just above 0.5 , then remains unchanged for a short while, before dropping sharply and finally exhibiting a slowly decreasing trend. According to the evolution curve for guanxi strength shown in Fig. 3, the longer the timespan, the lower the value of the entrepreneurial companies' guanxi strength.

Chinese organizations often derive their business practices from several types of guanxi (McNally 2011; Troilo and Zhang 2012), since strong, stable guanxi can compel a more effective implementation of contracts and reduce the risk of payment delinquency and business disputes (Yu et al. 2013). When the guanxi is particularly powerful, however, it can easily trigger unethical action. We must therefore impose strict business principles on the use of guanxi (Yu et al. 2013) and even attempt to consciously reduce its strength. What's more, it is obvious that as the scale of a entrepreneurial company's guanxi increases incrementally, the roles of its guanxi members become more complex and the time and opportunity that each member has for interacting with the entrepreneurial company decrease, hence reducing the strength of the guanxi. It is for these reasons that guanxi strength shows a decreasing trend in Fig. 3.

Figure 4 reflects the dynamic rule of how guanxi strength influences entrepreneurial companies' sales during their development process. According to Fig. 4, we know that in the first stage, guanxi strength gradually decreases until it reaches a point slightly above 0.5 , and the entrepreneurial companies' sales continue to increase incrementally. In the second stage, guanxi strength remains at a point slightly higher than 0.5 , but the entrepreneurial companies' sales show a linear increase, which can be attributed to the "rigid characteristics" of guanxi strength. In the third stage, guanxi strength starts to decline more gradually. Similarly, the entrepreneurial companies' sales also start to decrease, but the final sales are basically equal to the sales when the entrepreneurial companies' guanxi strength attained its highest point in the first stage. And here we should mention that the three stages discussed above correspond to the three

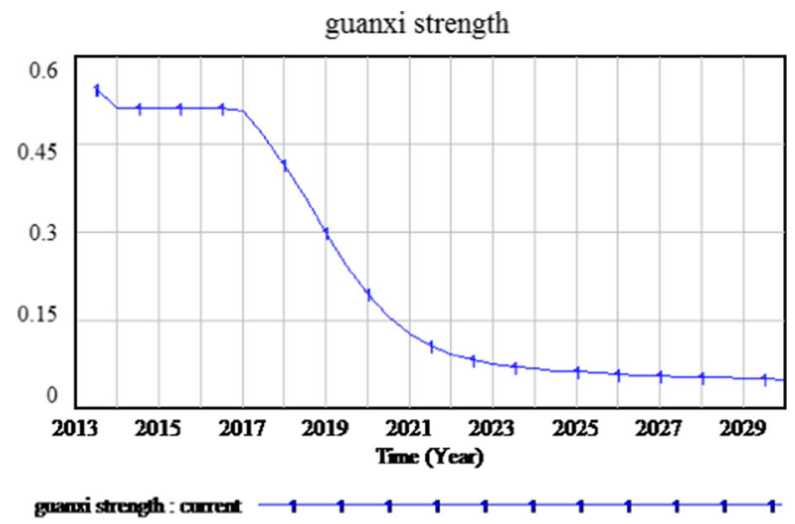

Fig. 3 Changes in guanxi strength during entrepreneurial companies' development 


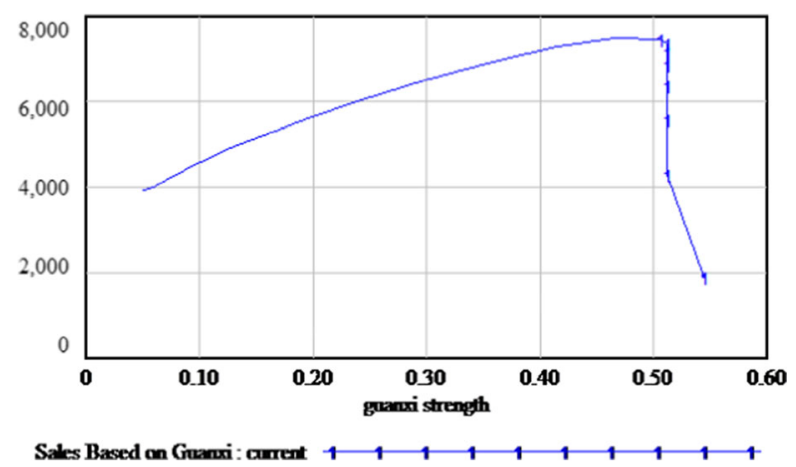

Fig. 4 The changing role of guanxi strength in influencing entrepreneurial companies' development

evolutionary stages of entrepreneurial companies' guanxi strength in Fig. 3. Integrating the results of Figs. 3 and 4, we can draw the following conclusion: From a long-term perspective, guanxi strength shows a decreasing trend and also positively influences entrepreneurial companies' development, but in the short term, it possesses rigid characteristics. This therefore supports Hypothesis 1a and Hypothesis $1 \mathrm{~b}$.

With regard to the dynamic relationships between guanxi strength and the development of entrepreneurial companies, the main conclusion we reached is that as guanxi strength continues to decline over time, the value it creates (represented as sales) also decreases (as shown in Fig. 4). From the perspective of the pressures placed on guanxi strength, entrepreneurial companies need strong guanxi to reduce the costs of company establishment during the early stages (Kreiser et al. 2013), especially in an absent or irregular regulatory environment, since to promote development they must depend on the high level of trust and interpersonal reciprocal obligations inherent to strong guanxi. This dependence on strong ties gradually decreases, however, as the companies become stronger, a rules-based and impersonalized transaction structure takes shape and they accumulate experience (Arregle et al. 2013).

From the perspective of long tail economics (Anderson 2004), although the value created for entrepreneurial companies by weak guanxi or guanxi during certain periods is not very high, it can definitely become equal to or even bigger than strong guanxi after being integrated for a long period of time. Here, we take it a step further: when guanxi strength is reduced to a certain value, its influence on the entrepreneurial companies has rigid characteristics (as shown in Fig. 4). In other words, the strength of the guanxi remains unchanged, but the sales based on guanxi continue to increase. When overall guanxi strength declines to a certain point, the quality of the relationships with strong guanxi members in the network will stand out (Semrau and Werner 2013). These usually exist within the closest, tightest circles and can completely meet the resource demands of the entrepreneurial companies. Furthermore, the value created for the entrepreneurial companies increases incrementally.

\section{Changes in guanxi scale and its influence on entrepreneurial companies' development}

The results of the system dynamics simulation (as shown in Fig. 5) further reveal that during entrepreneurial companies' development, the scale of their guanxi constantly exhibits an increasing trend. As we can see from Fig. 5, however, the slope of the 


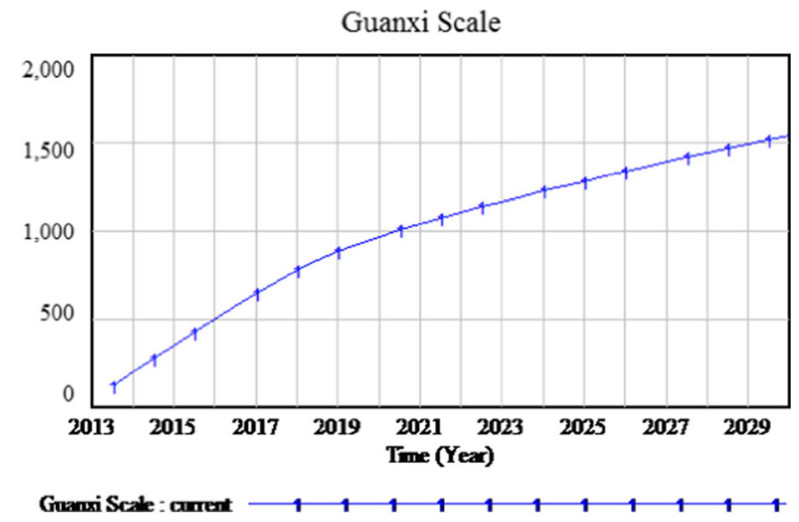

Fig. 5 Changes in guanxi scale during entrepreneurial companies' development

evolution curve gradually decreases, from which we can determine that the speed at which the entrepreneurial companies' guanxi scale grows gradually slows down.

Pre-existing guanxi members of entrepreneurial companies will publically promote the companies' prestige, brand, culture and so forth, thus attracting potential external members to the guanxi network. Meanwhile, the internal guanxi members will also introduce external members into the network. It is consequently inevitable that the scale of the entrepreneurial companies' guanxi will increase (as shown in Fig. 5). Yu et al. (2013) think that entrepreneurial companies need to build guanxi continuously in order to assure long-term relationships with suppliers, manufacturers, distributors and customers. From this point of view, we can conclude that $\mathrm{Yu}$ et al. have proposed that guanxi scale is positively related to long-term value. Troilo and Zhang (2012) also think that "it seems logical for entrepreneurs to cultivate guanxi as much as possible in China, in order to protect themselves and to seek more equitable treatment by the state". The results of our research do not support these conclusions, since many types of guanxi that were once very useful for company development can not only gradually become useless, but also even have a braking effect on the development process (Arregle et al. 2013).

Figure 6 reflects the dynamic rule of how guanxi scale influences the sales of entrepreneurial companies during their development process. As we can see from Fig. 6, when an entrepreneurial company's guanxi scale increases from the initial value

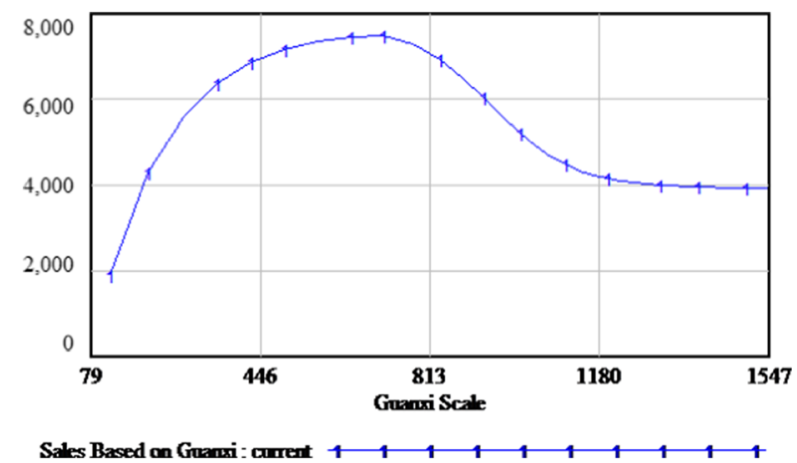

Fig. 6 The Changing role of Guanxi scale in influencing entrepreneurial companies' development 
to a certain critical value, the sales it creates reach a maximum. After that, the sales start to decrease and then reach a comparatively stable level, though the companies' guanxi scale remains an increasing trend. It is obvious that the scale of the guanxi of entrepreneurial companies will increase incrementally during their development process. However, only a certain scale can positively influence sales. What's more, in the final stage, the sales that the scale of guanxi can generate for entrepreneurial companies are basically constant. Integrating the results of Figs. 5 and 6, we can draw the following conclusion: From a long-term perspective, guanxi scale continues to increase, and when it is below a critical value, the development of the entrepreneurial companies correlates positively with the guanxi scale, whereas when it is above that critical value, it is not in correlation with the guanxi scale. This therefore supports Hypothesis $2 \mathrm{a}$ and Hypothesis $2 \mathrm{~b}$.

In the research concerning the effects of network size and relationship quality on access to start-up resources, Semrau and Werner (2013) concluded that a nascent entrepreneur's network scale has a positive, but concave, relationship to the start-up resources it secures. In the short term, our research results are similar to those of Semrau and Werner (2013): that is, the increase in entrepreneurial companies' guanxi scale can impel increased sales based on guanxi, but marginal utility decreases. However, in the long term, the marginal utility of the guanxi scale remains valued at zero: that is, an increase in the scale of guanxi will not lead to an increase in sales based on guanxi. The main reason for this difference in results is the fact that our research objects differ from those of Semrau and Werner. Our research objects are entrepreneurial companies with many years of entrepreneurial experience rather than nascent entrepreneurs. Another reason is that although the value of some guanxi members gradually decreases until it disappears, newly entered guanxi members compensate for that loss and thus the value created by the overall guanxi scale remains constant (as shown in Fig. 6). As a result, when below the critical value, development correlates positively with guanxi scale; when above the critical value, it correlates negatively with guanxi scale, which ultimately maintains a constant value.

\section{Changes in guanxi structure and its influence on entrepreneurial companies' development}

The results of the system dynamics simulation (see Fig. 7), show that during the development of entrepreneurial companies, their guanxi structure increases in the short term, but not for long, and then started to gradually decrease. We can deduce from the slope of the decreasing evolution curve for guanxi structure in Fig. 7 that the decreasing speed of growth in the entrepreneurial companies' guanxi structure eventually tapers out. This therefore supports Hypothesis $3 \mathrm{a}$.

Figure 8 reflects the dynamic rule of how guanxi structure influences the sales of entrepreneurial companies during their development process. According to Fig. 8, in the first stage, entrepreneurial companies' sales go up as guanxi structure increases; then, in the second stage, as guanxi structure gradually decreases, sales continue up for a while before dropping, in an upside-down U-shape. These two stages correspond to the evolution stages of the entrepreneurial companies' guanxi structure shown in Fig. 7. By integrating the results from Figs. 7 and 8, we can draw the following conclusion: From a long-term perspective, guanxi structure goes up and then down, and the 


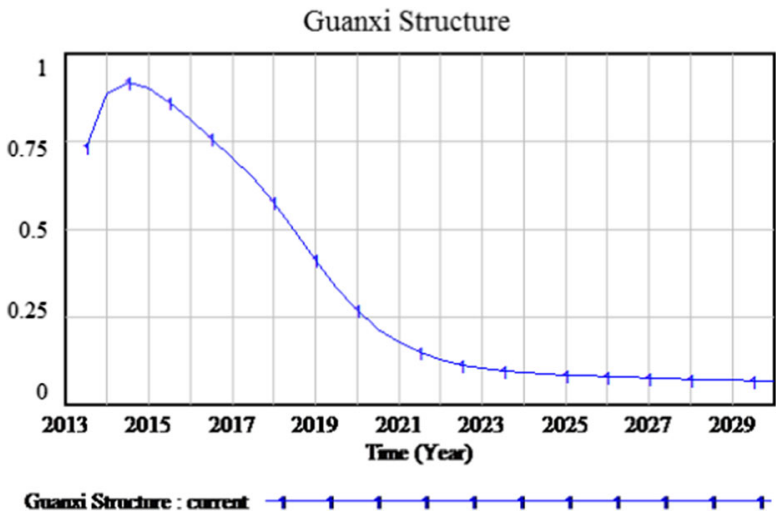

Fig. 7 Changes in Guanxi structure during entrepreneurial companies' development

influence of guanxi structure on the development of entrepreneurial companies exhibits a U-shaped trend. This therefore supports Hypothesis $3 b$.

From the point of "chaxugeju" in China (a differential mode of association) (McNally 2011), there is inevitably an accepted hierarchy in the guanxi network. That is, it is unavoidable for some guanxi members to be located in close, at the core of the guanxi structure, while others are on the margins. This rule can be adopted for the guanxi structure of entrepreneurial companies, as well. As entrepreneurial companies develop, new guanxi members will continue to join their guanxi networks, bringing in new resources for them in the short term, thus increasing the density of the guanxi structure (as shown in Fig. 8, which demonstrated that sales based on guanxi increase with guanxi structure). Meanwhile, the guanxi structure of the entrepreneurial companies continues to expand, but much of what the new guanxi members bring in are slack resources (Semrau and Werner 2013). Accordingly, some guanxi members leave the core guanxi structure, which then starts to diminish (as shown in Fig. 7). At this point, the sales corresponding to guanxi structure increase for a while and then start to decrease, exhibiting a U-shaped trend (as shown in Fig. 8). Besides, when guanxi structures become dense, a strong sense of group identity and favoritism starts to emerge in the network. The efficacy of the guanxi therefore decreases and some types of guanxi can even start to produce negative effects, leading to a concomitant decrease in the sales corresponding to guanxi structure.

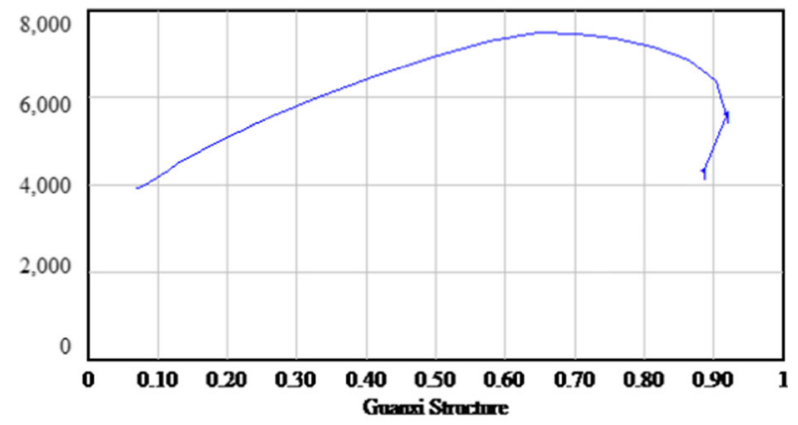

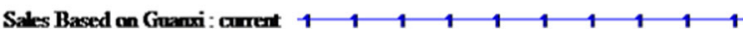

Fig. 8 The changing role of guanxi structure in influencing entrepreneurial companies' development 


\section{Sensitivity analysis}

In order to take the uncertainty surrounding the assumptions of the model into account a sensitivity analysis has been conducted. It should show the extent to which different variables affect the outcome of the model by entering a range of values for a particular variable while keeping all others constant. We examined the sensitivity of the variables for guanxi strength, guanxi scale, guanxi structure and sales based on guanxi with respect to the four constants in the model. (i.e. transformation rate, decay rate, life cycle and value creation coefficient). The sensitivity was analyzed by a variation based on a $10 \%$ increase or decrease in the four constants. The results are shown in Appendix 3. As can be seen in Appendix 3, the variables for guanxi strength, guanxi scale and guanxi structure are sensitive to just one of the four constants; the variable for guanxi strength is sensitive to the constant for decay rate, the variable for guanxi scale to constant for transformation rate and the variable for guanxi structure to the constant for decay rate. In addition, the variable for sales based on Guanxi is not sensitive to any of the four constants.

\section{Discussions}

\section{Theoretical contributions}

Our research makes a number of theoretical and empirical contributions to the literature on entrepreneurial companies' guanxi. The existing research either does not specifically distinguish between the different attributes of guanxi (Webb et al. 2010; Wright et al. 2008; Liao and Sohmen 2001), which include strength, scale and structure (Yu et al. 2013; Park and Luo 2001; McNally 2011) and should be considered comprehensively, or covers only some of them. Therefore, it is very difficult to form a comparatively complete understanding of the entrepreneurial companies' guanxi. Besides, although prior studies have pointed out that the dynamic characteristics of guanxi, such as the rule that its structure and strength change over time, have been widely recognized in the academic literature as an interesting topic with regard to China (Batjargal and Liu 2002) and that the dynamic development of guanxi is influenced by a great variety of factors, such as institutional, strategic and organizational factors (Park and Luo 2001), the question of how guanxi evolves within the venture-building process has not yet been answered (Yu et al. 2013).

Based on the shortcomings outlined above, the main contributions of our paper can be described as follows: From a theoretical point of view, our research enriches the understanding of "guanxi" of entrepreneurial companies in China. The connotation of "guanxi" was defined from the dimensions of strength, scale and structure and the dynamic rules of "guanxi" were also summarized. In addition, the paper establishes the link between "guanxi" and the development of entrepreneurial companies more clearly, based on a comprehensive study of dynamic interaction rules between guanxi and other variables.

Empirically, prior studies that addressed the issue of how guanxi influences entrepreneurial companies' performance either adopted a qualitative case study methodology (Yu et al. 2013; McNally 2011) or used structural equation modes (Yang and Jiang 
2010) or regression models (Park and Luo 2001; Zolin et al. 2011; Boso et al. 2013; Arribas et al. 2012). Although these researchers explored the effects of guanxi on entrepreneurial companies' development, they failed to depict how guanxi changes over time or how it dynamically influences development through its different attributes. Therefore, another important contribution of our research is that it furthers the understanding of the role of guanxi in influencing entrepreneurial companies' development, based on prior research (Yu et al. 2013; Park and Luo 2001; Yang and Jiang 2010; Batjargal and Liu 2002; Troilo and Zhang 2012; McNally 2011; Liao and Sohmen 2001; Arribas et al. 2012; Puffer et al. 2010; Semrau and Werner 2013; Lockett et al. 2006; Karra et al. 2006), by highlighting the comprehensive attributes of guanxi and their dynamics, interactions and effects.

\section{Management implications}

In emerging countries, business support systems are very weak and commercial laws and regulations cannot be formulated and implemented effectively. It is uncertain whether entrepreneurial companies can achieve success if they depend solely on market information and formal contracts, and they must therefore rely on guanxi to compensate for institutional paucities (De Clercq et al. 2010; Boso et al. 2013) and improve entrepreneurial efficiency. But guanxi is not a panacea for entrepreneurial activities in China, and for it to function well, it needs to be paired with institutional, strategic and organizational attributes (Park and Luo, 2001). Hence, in the long term, guanxi is necessary but insufficient for the development of entrepreneurial companies (Yeung and Tung 1996; Batjargal and Liu 2002).

Given this, entrepreneurial companies in China must consciously build, develop and maintain all kinds of guanxi, but should not depend exclusively on it. In other words, we hope that entrepreneurial companies in China are not all "guanxi qiye". Chinese companies can benefit from guanxi in the process of entrepreneurship, just like people sailing on the sea benefit from a boat or people get eggs from hens, achieving a lot by doing a little. However, entrepreneurial companies must also possess the primary foundations and potential core advantages provided by technology, human resources, professional management, a flexible corporate culture.

Guanxi is not only very important in China, but also widely distributed around the world through the Chinese Diaspora. Chen et al. (2011) have shown that a guanxi network based on trust, satisfaction and commitment enhances the performance of entrepreneurial companies. A guanxi network is built up by the Chinese diaspora to achieve a higher firm performance. Based on guanxi strength, guanxi scale and guanxi structure a superior firm performance should be achieved (Zolin et al. 2011; Semrau and Werner 2013; Yang and Jiang 2010). According to Kelley et al. (2013), a key challenge for many companies, including firms of the Chinese diaspora, is that they are depending excessively on the guanxi network. For instance, they might aggressively pursue guanxi strength, guanxi scale and guanxi structure. Therefore, following the specific rules while constructing and utilizing guanxi, might be the only way for Chinese diaspora to establish the business. However, guanxi networks are not influenced by a single factor (Klyver et al. 2008), but by many factors, such as cultural diversity. In addition, the effects of guanxi on entrepreneurial 
companies are most evident in terms of market exploitation that results in influencing sales performance positively and directly (Lau and Bruton 2011) or has a moderating effect by influencing the relationship among firm strategies, entrepreneurial orientation, market orientation and sales (Stam and Elfring 2006; Boso et al. 2013), thus indirectly promoting entrepreneurial companies' sales growth. Therefore, in the process of using guanxi to promote the development of entrepreneurial companies, we should analyze guanxi according to the circumstances and adopt different guanxi practices to accommodate the diversity of cultures, development phases, strategic orientations and so on, on the basis of which we can make dynamic judgments and choices about guanxi strength, scale and structure, hence effectively exerting the integrated power of guanxi.

Limitations and suggestions for future research

Young and old firms have different requirements with regard to guanxi: the former use guanxi intensively, while the latter use it extensively (Park and Luo 2001). In our research, focused on the variables of system dynamics models, we tried to investigate entrepreneurial companies of different ages in Chinese pharmaceutical industry in order to obtain an average for the whole industry. Therefore, we did not specifically distinguish between the attributes of guanxi among young and old firms and how they influence the development of entrepreneurial companies.

Building guanxi is an important step for starting a business (Yu et al. 2013). Entrepreneurial companies can either establish guanxi first and then start the business or start the business and establish guanxi at the same time. Our system dynamics models were established without taking into consideration the sequence relationships in the initial stages (i.e., establishing guanxi first or starting a business first).

The construction and maintenance of guanxi place simultaneous demands in terms of moral restraints (e.g., "mianzi" and "jiaoqing") and rule restraints (e.g., formal contracts) (Yang and Jiang 2010). In our research, the guanxi established between entrepreneurial companies in the pharmaceutical industry and hospitals (including prescribing doctors), drug stores (including medical practitioners) and so on includes moral and rule restraints. Under these two kinds of constraints, the rules for how different attributes of guanxi dynamically influence the development of entrepreneurial companies requires further research.

We think that the construction and application of "guanxi" positively contribute to the development of Chinese companies (Yang and Jiang 2010). However, further research has to demonstrate whether this theory can be adapted to other countries. In this context we recommend that future researchers should employ empirical and theoretical studies to explore "guanxi" in more detail.

Despite the limitations mentioned above, we believe that the results of our research contribute to a more comprehensive understanding of entrepreneurial companies' guanxi and proper recognition of how guanxi dynamically influences entrepreneurial companies. 


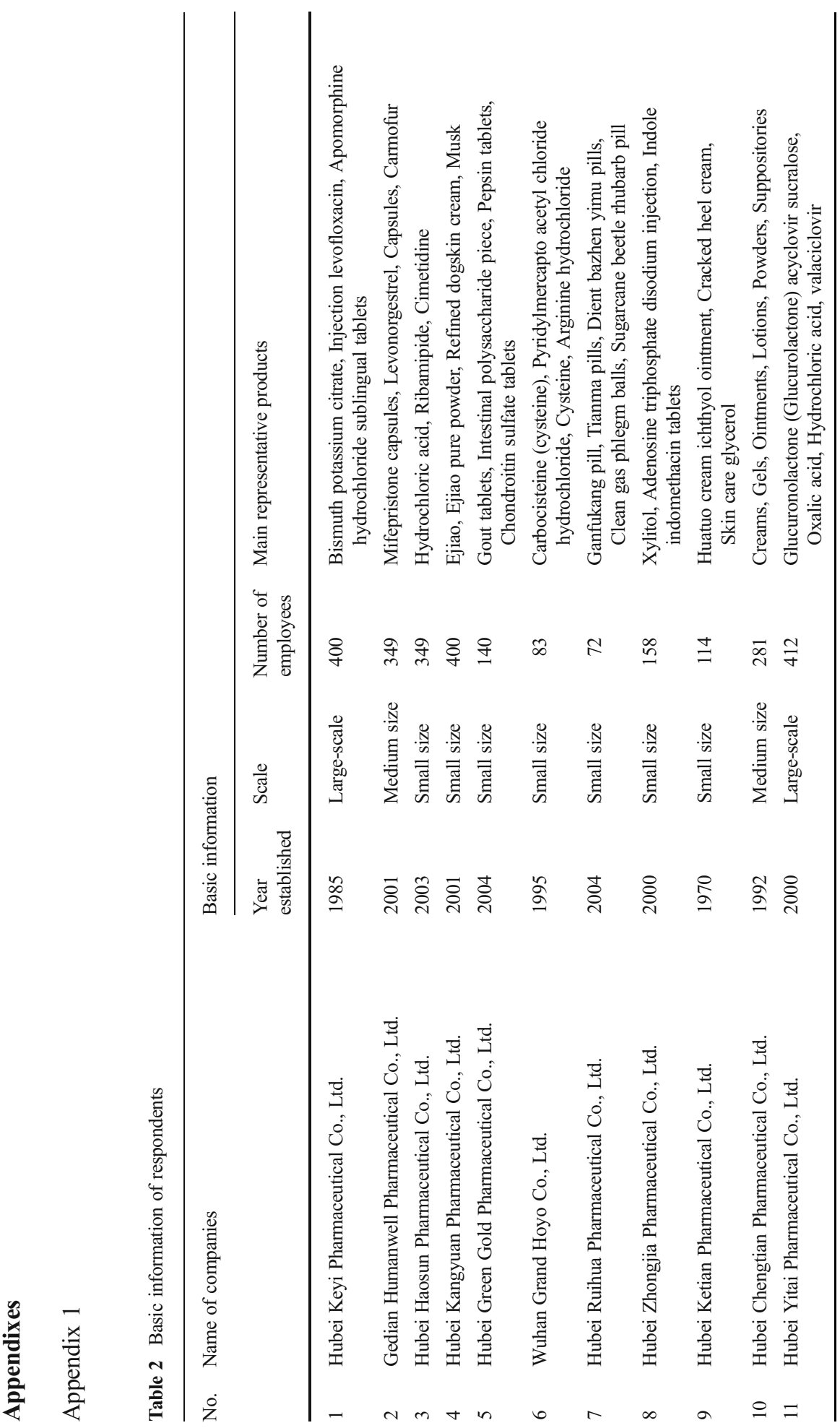




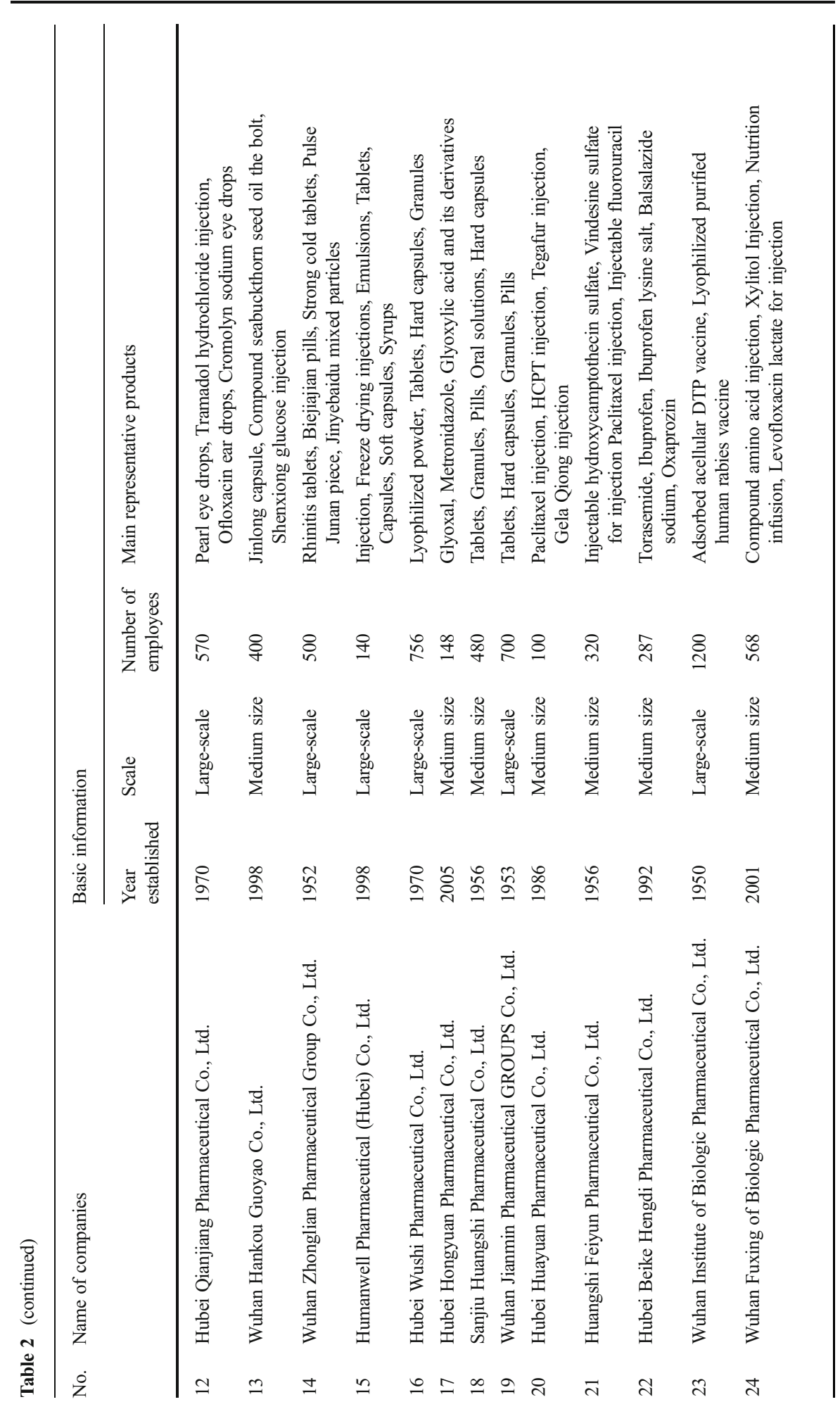




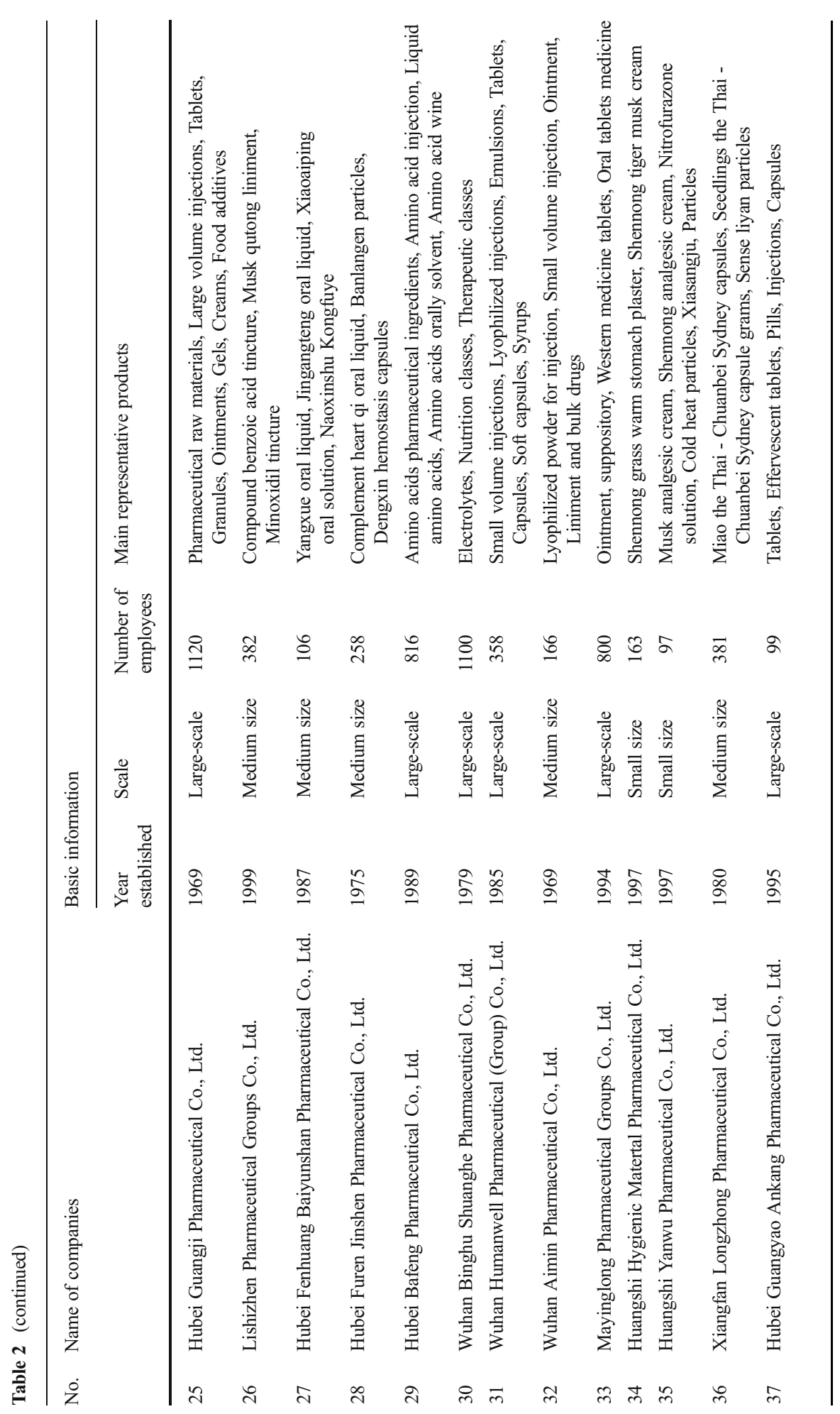




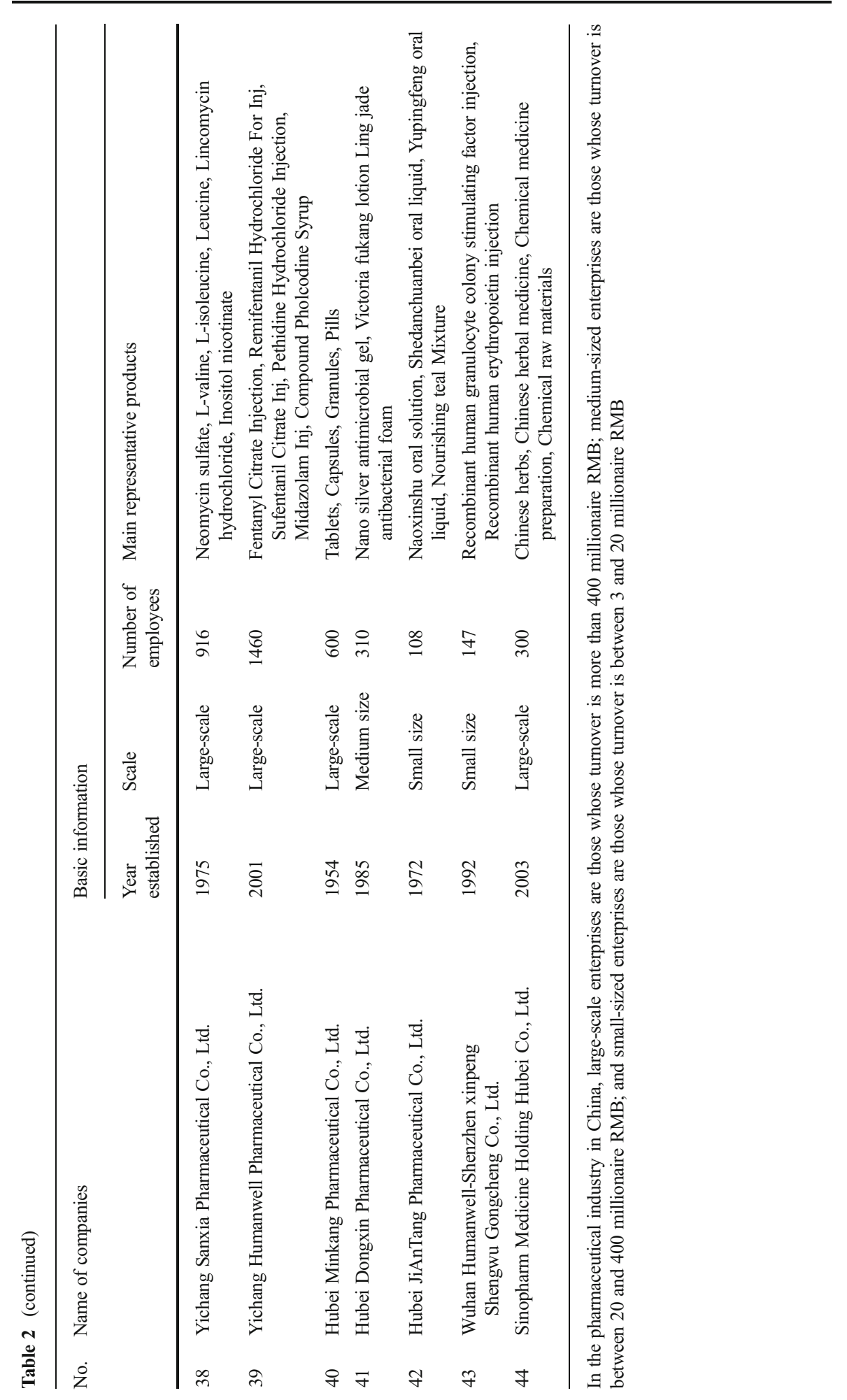


Appendix 2

\section{Variables}

Level variables Guanxi Scale: Entrepreneurial companies are willing to consciously establish guanxi, but not all guanxi are effective. Just like "a friend in need is a friend indeed," the members in an entrepreneurial company's guanxi network should indeed represent connections with those companies or institutions who are willing to help the entrepreneurial company even without high returns (Arribas et al. 2012; Yu et al. 2013; Batjargal and Liu 2002; Semrau and Werner, 2013).

Guanxi Structure: Entrepreneurial companies' guanxi structure is decided by not only the links among guanxi members, but also the rank of importance and necessity of guanxi members (Theingi and Phungphol 2008; Yang and Jiang 2010; Arribas et al. 2012).

Sales Based on Guanxi: Guanxi leads to higher firm performance (e.g., sales growth) and creates some values for entrepreneurial companies (Park and Luo 2001; Yu et al. 2013; Yang and Jiang 2010; Webb et al. 2010).

Rate variables Entry: When an entrepreneurial company wants to expand market share or overcome legitimacy barriers, it will engage in new guanxi (Yu et al. 2013; Park and Luo 2001).

Exit: For reasons belonging to either the guanxi members themselves or the entrepreneurial companies, some members may be eliminated from the entrepreneurial companies' key circle or even the guanxi network (Zolin et al. 2011; Ucbasaran et al. 2003).

Clustering coefficient: Some guanxi members are in the core layer or closed clique of the entrepreneurial company's guanxi network (Park and Luo 2001; Arribas et al. 2012; Batjargal and Liu 2002).

Loose degree: Some guanxi members do not become close to the entrepreneurial company (Park and Luo 2001; Granovetter 1985; Pitt et al. 2006).

Sales growth: Entrepreneurial companies' sales growth can be created by new guanxi (Park and Luo 2001; Yu et al. 2013; Boso et al. 2013; Yang and Jiang 2010).

Cost: Guanxi cultivation has become very costly (Park and Luo 2001; Troilo and Zhang 2012) and entrepreneurial companies must pay for it.

Auxiliary variables Potential guanxi scale: Many of the entrepreneurial company's stakeholders have the potential to enter the guanxi network (Evald and Bager 2008; Chen 2011).

Guanxi strength: The strength of ties, connections or relationships between an entrepreneurial company and its guanxi members (Park and Luo 2001; Boso et al. 2013; Chen 2011). 
Mutual trust: Trust is not about whether the entrepreneurial companies believe their social network members, but to what degree they can believe one another ( $\mathrm{Yu}$ et al. 2013; Caliendo et al. 2012).

Interactions: Entrepreneurial companies and their guanxi members like to communicate by telephone, mail, face-to-face visits and activities for promoting friendship, whether or not they are cooperating (Park and Luo 2001; Boso et al. 2013).

Reciprocity: Real guanxi should involve mutually beneficial cooperation, in which both the entrepreneurial company and the guanxi members benefit (Yu et al. 2013; Puffer et al. 2010; Park and Luo 2001; Batjargal and Liu 2002).

Constants Transformation rate: Through "guanxi investments" made for commercial reasons, some potential guanxi members will become real guanxi members for the entrepreneurial company (Troilo and Zhang 2012).

Life cycle: As time goes on, some guanxi members and entrepreneurial companies that started with close collaborations will eventually choose to end them (Haggerty and Haggerty 2011; Batjargal and Liu 2002).

Decay rate: Not all of an entrepreneurial company's guanxi necessarily maintain their value-creation ability. As time goes by, that ability decreases or destructive actions can even occur (Yang and Tang 2004; Yu et al. 2013).

Value creation coefficient: Different guanxi have different value-creation abilities (Park and Luo 2001; Troilo and Zhang 2012).

Appendix 3

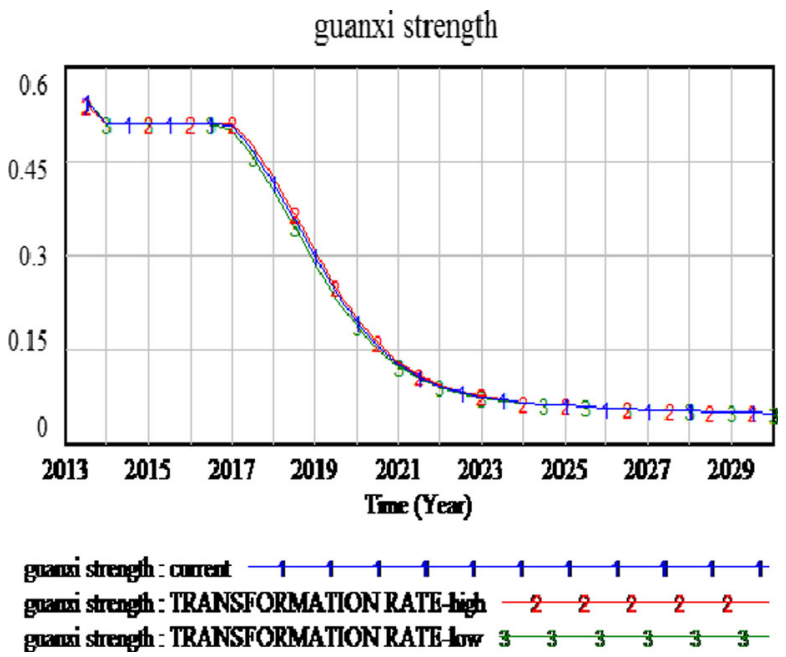

Fig. 9 Sensitivity analysis of the correlation between sales based on guanxi and guanxi strength on transformation rate 


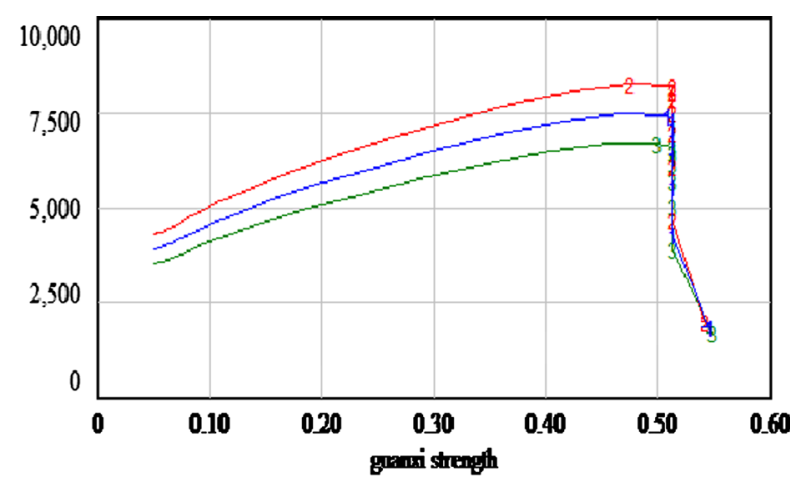

Sales Based on Guari : cancent 1

Sales Based on Gurai: TRANSFORMATION RATK-high $\begin{array}{lllll}2 & 2 & 2\end{array}$

Stes Based on Gmari: : TRANSTORMATION RATK-1m: $\begin{array}{lllll}3 & 3 & 3 & 3\end{array}$

Fig. 10 Sensitivity analysis between guanxi strength and transformation rate

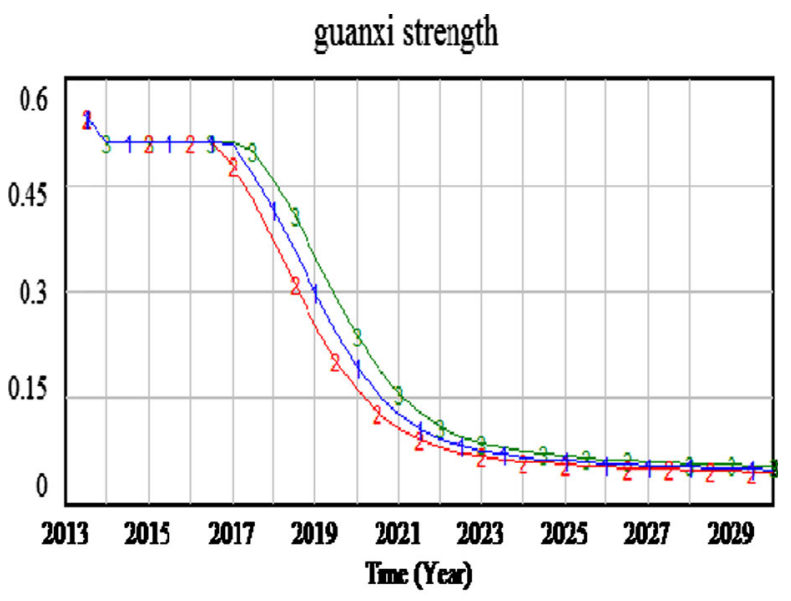

granistengh: curet -1

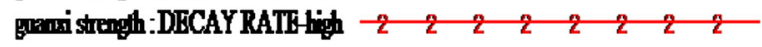

grami strength:DFCAY RATE-Lw $\begin{array}{lllllllll}3 & 3 & 3 & 3 & 3 & 3 & 3 & 3\end{array}$

Fig. 11 Sensitivity analysis of the correlation between sales based on guanxi and guanxi strength on decay rate 


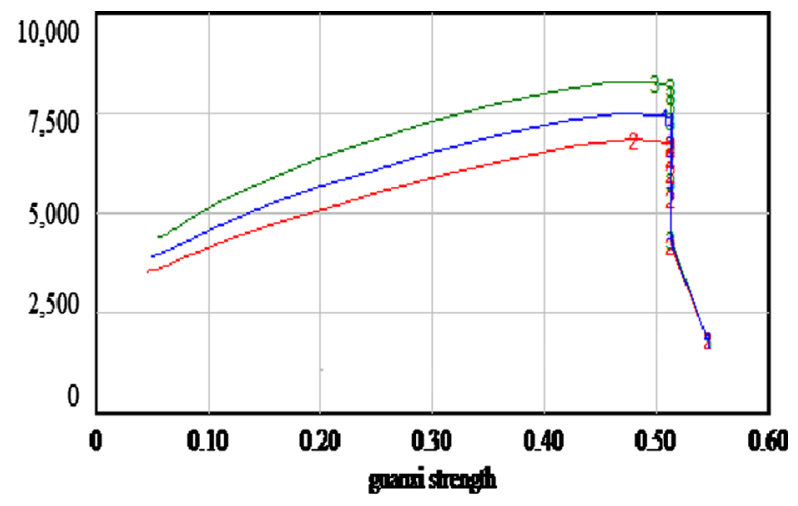

Siles Based on Guami:Curet $1 \begin{array}{llllllllll}1 & 1 & 1 & 1 & 1 & 1 & 1 & 1 & 1 & 1\end{array}$

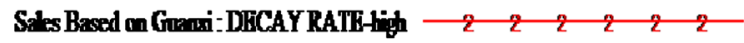

Siles Based on Garmi:DFCAY RATE-Lw $\begin{array}{lllllll}3 & 3 & 3 & 3 & 3 & 3 & 3\end{array}$

Fig. 12 Sensitivity analysis between guanxi strength and decay rate

guanxi strength

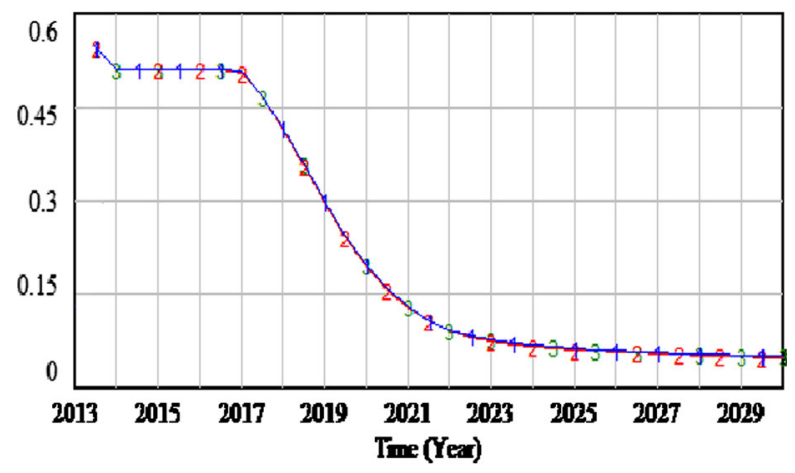

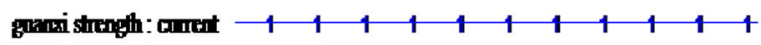

grami strength : LIFE CYCLE ligh $\begin{array}{lllllllll}2 & 2 & 2 & 2 & 2 & 2 & 2 & 2\end{array}$

grami stength:LIFE CYCLLE- $\begin{array}{lllllllll}3 & 3 & 3 & 3 & 3 & 3 & 3 & 3 & 3\end{array}$

Fig. 13 Sensitivity analysis of the correlation between sales based on guanxi and guanxi strength on life cycle 


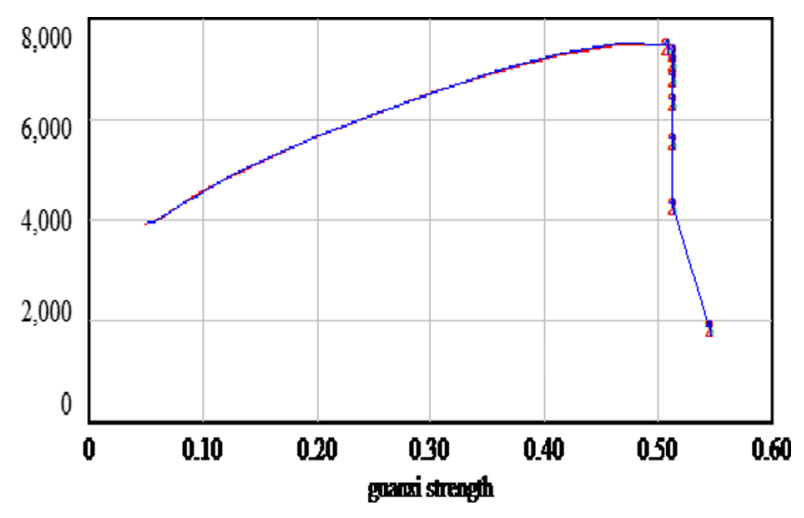

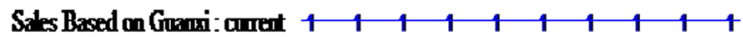

Soles Based on Garmi:LIFG CYCLLE-hinh 2

Sales Based on Cmanx : IIFR CYCLIF-Hw $\begin{array}{llllllll}3 & 3 & 3 & 3 & 3 & 3 & 3\end{array}$

Fig. 14 Sensitivity analysis between guanxi strength and life cycle

guanxi strength

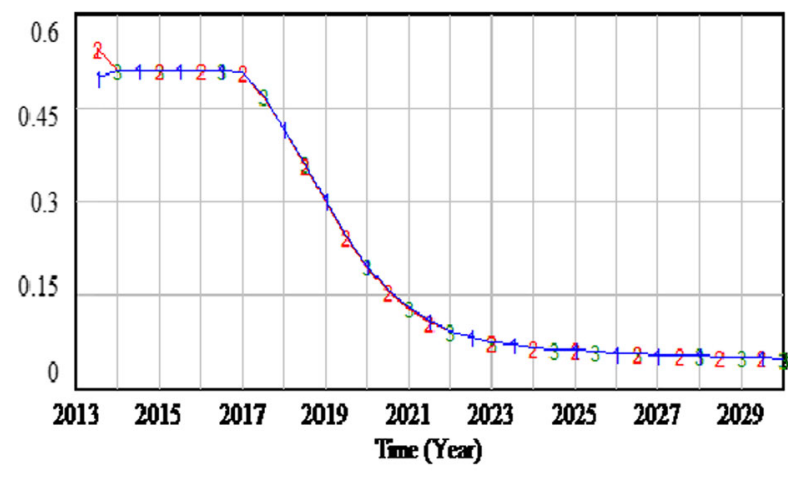

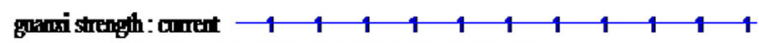
grani strength : VALUL CRFATION COFFFICIFNT high 2

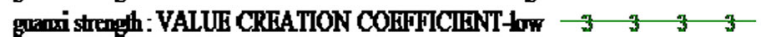

Fig. 15 Sensitivity analysis between guanxi strength and value creation coefficient 


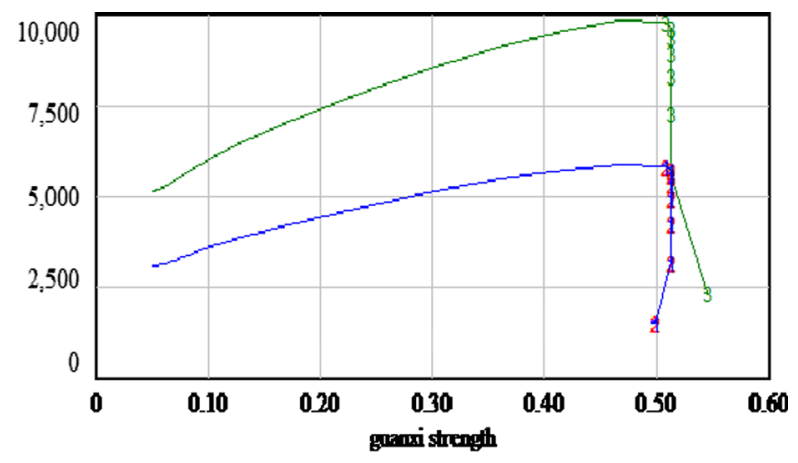

Sales Based on Guani : content

Sales Based on Garmi : VALUL CRFATION COFFFICIIINT 1 low $2-2$

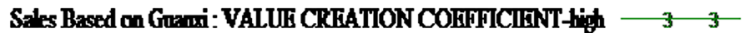

Fig. 16 Sensitivity analysis of the correlation between sales based on guanxi and guanxi strength on value creation coefficient

Guanxi Scale

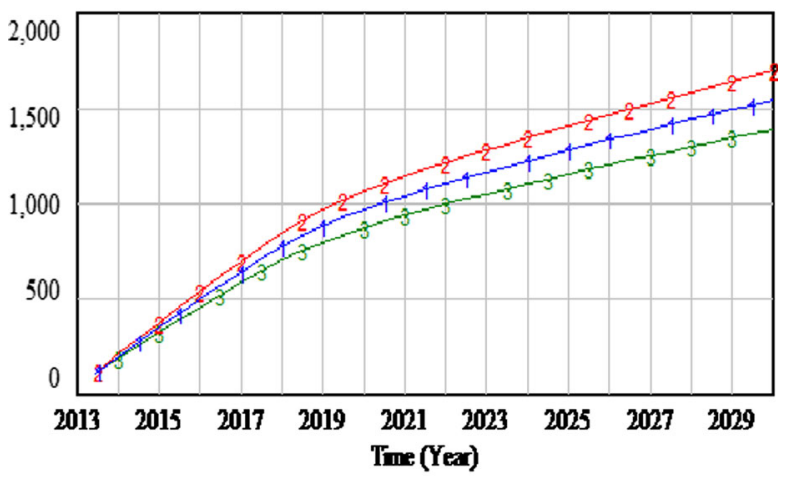

GuariScale:cument $\quad \begin{array}{lllllllllll}1 & 1 & 1 & 1 & 1 & 1 & 1 & 1 & 1 & 1 & 1\end{array}$

Grani Scale : TRANSFORMATION RATE-high $\begin{array}{llllll}2 & 2 & 2 & 2 & 2\end{array}$

Guari Sale : TRANSFORMATIONRATK-10\%

Fig. 17 Sensitivity analysis of the correlation between sales based on guanxi and guanxi scale on transformation rate 


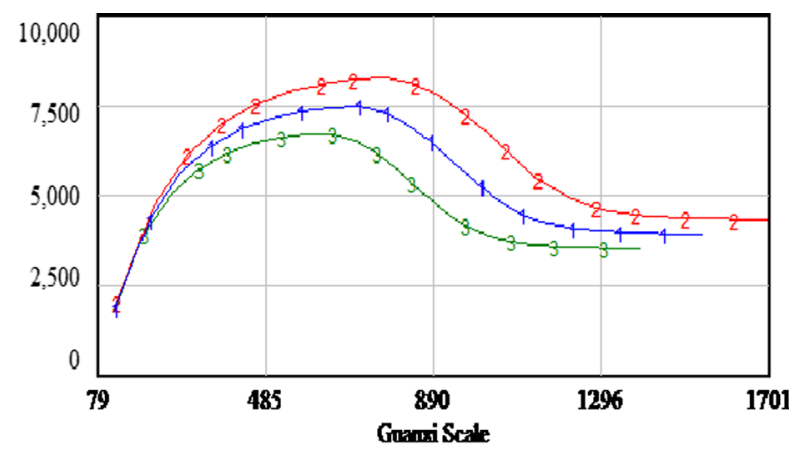

Soles Based on Goani: concut $1 \begin{array}{llllllllll}1 & 1 & 1 & 1 & 1 & 1 & 1 & 1 & 1 & 1\end{array}$ Sales Based on Guari: TRANSFORMATION RATE-high $\begin{array}{lllll}2 & 2 & 2\end{array}$

Soles Based on Grani : TRANSFORMATION RATK-lw $\begin{array}{llll}3 & 3 & 3 & 3\end{array}$

Fig. 18 Sensitivity analysis between guanxi scale and transformation rate

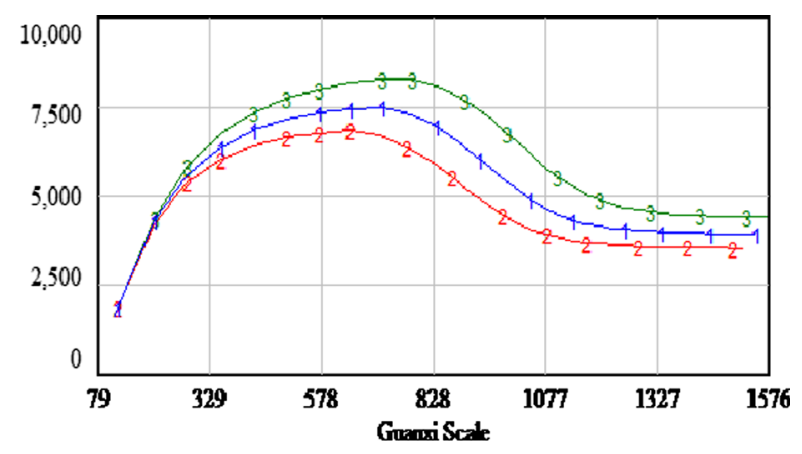

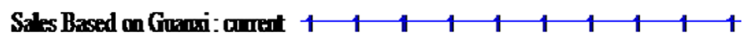
Sales Based on Grani : DBCAY RATB-high $2 \begin{array}{llllll}2 & 2 & 2 & 2 & 2\end{array}$

Siles Based on Gmani : DFCAY RATK - low $\begin{array}{llllllll}3 & 3 & 3 & 3 & 3 & 3 & 3-\end{array}$

Fig. 19 Sensitivity analysis between guanxi scale and decay rate 


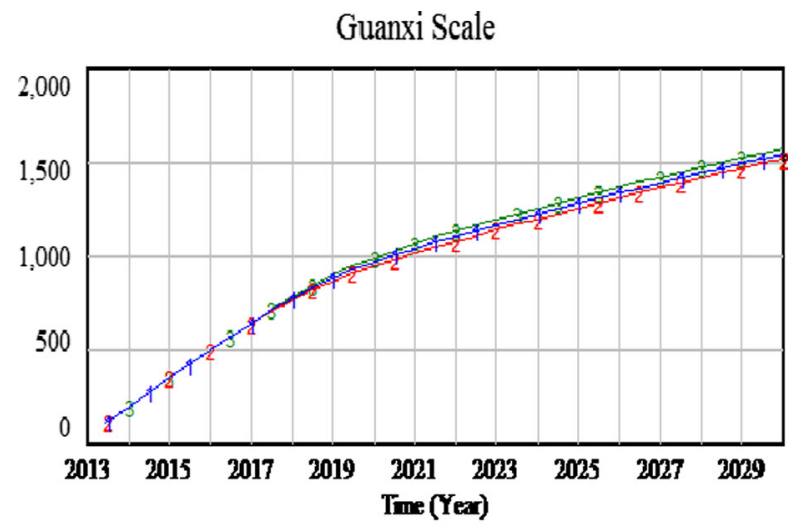

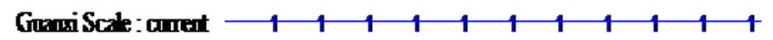

Ganki Scale : DFCAY RATEhigh $\begin{array}{lllllllll}2 & 2 & 2 & 2 & 2 & 2 & 2 & 2\end{array}$

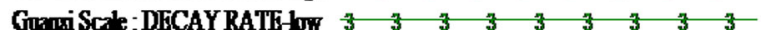

Fig. 20 Sensitivity analysis of the correlation between sales based on guanxi and guanxi scale on decay rate

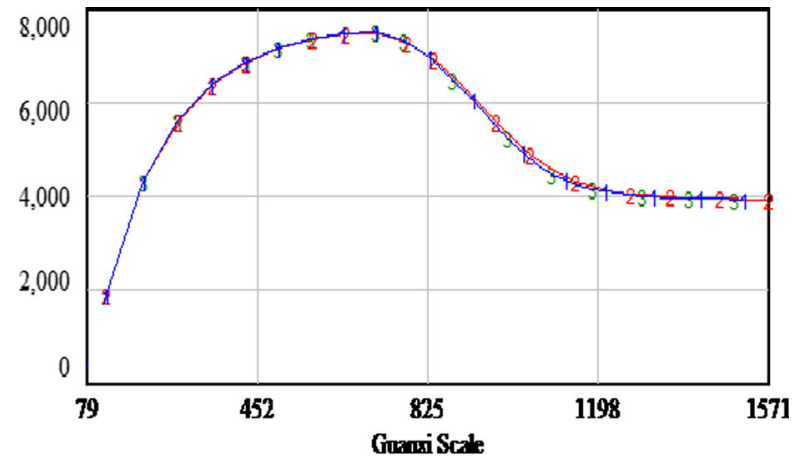

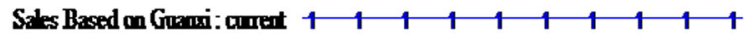

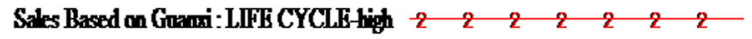

Sales Based on Grami: LIFE CYCLE - low $\begin{array}{lllllll}3 & 3 & 3 & 3 & 3 & 3 & 3\end{array}$

Fig. 21 Sensitivity analysis of the correlation between sales based on guanxi and guanxi scale on life cycle 


\section{Guanxi Scale}
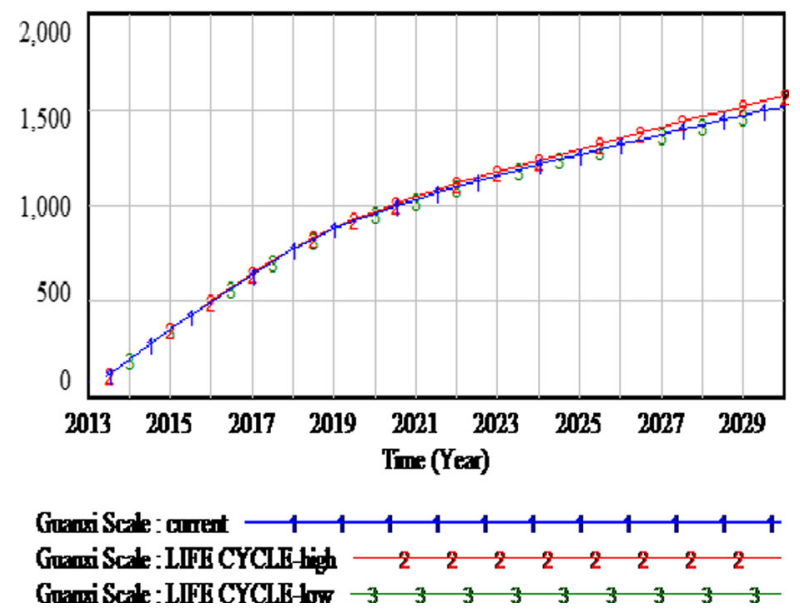

Fig. 22 Sensitivity analysis between guanxi scale and life cycle

\section{Guanxi Scale}

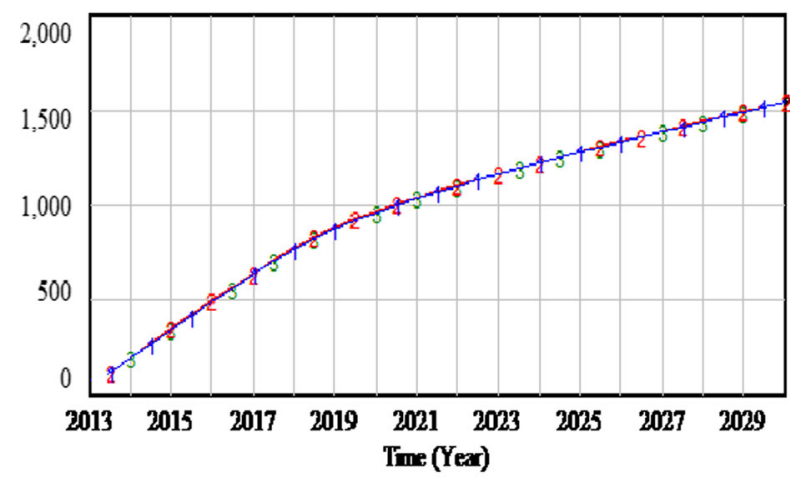

Guari Sale : cament $\longrightarrow$

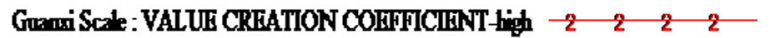

Ganki Sale : VALUIF CRFATION COFFFICIFNT - How $\begin{array}{lllll}3 & 3 & 3 & 3\end{array}$

Fig. 23 Sensitivity analysis between guanxi scale and value creation coefficient 


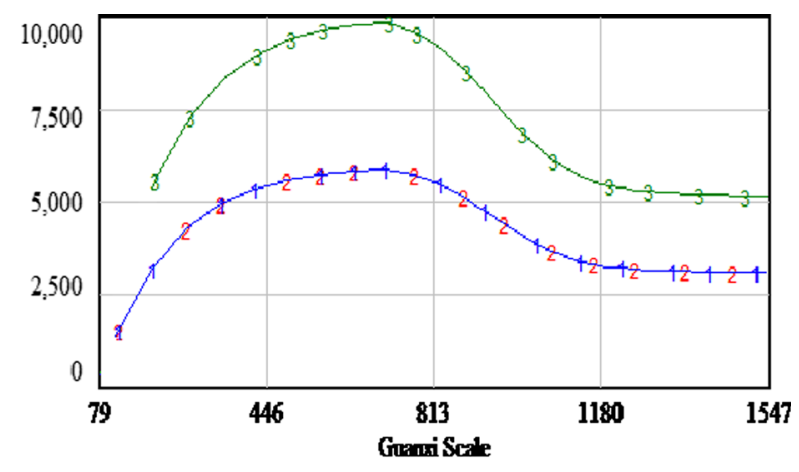

Sales Based on Guani : contert 1

Sales Based on Guani: VALLUE CRFATION COFFFICIFINT -

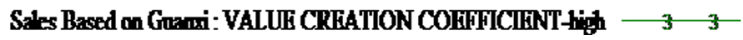

Fig. 24 Sensitivity analysis of the correlation between sales based on guanxi and guanxi scale on value creation coefficient

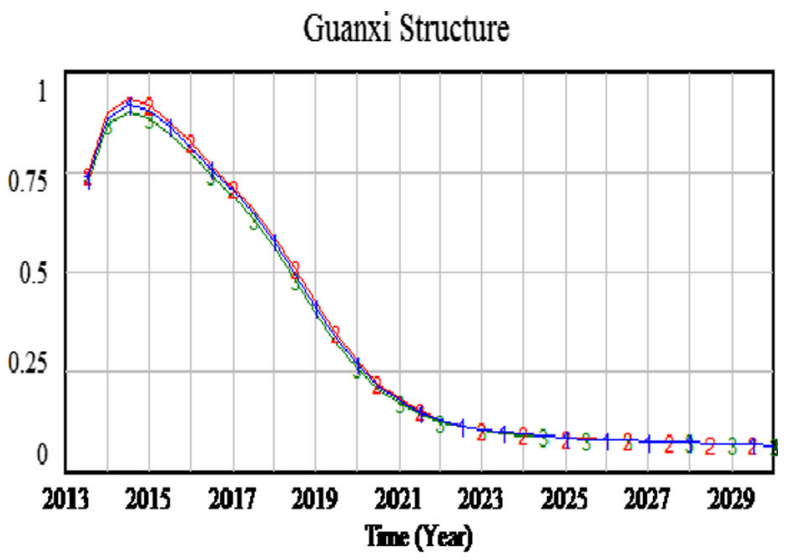

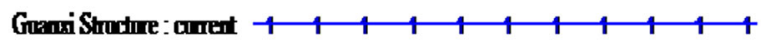

Guani Stuctur: TRANSFORMATIONRATE-high $\begin{array}{llllll}-2 & 2 & 2 & 2 & 2\end{array}$

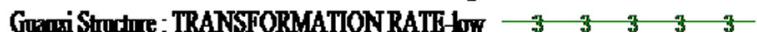

Fig. 25 Sensitivity analysis of the correlation between sales based on guanxi and guanxi structure on transformation rate 


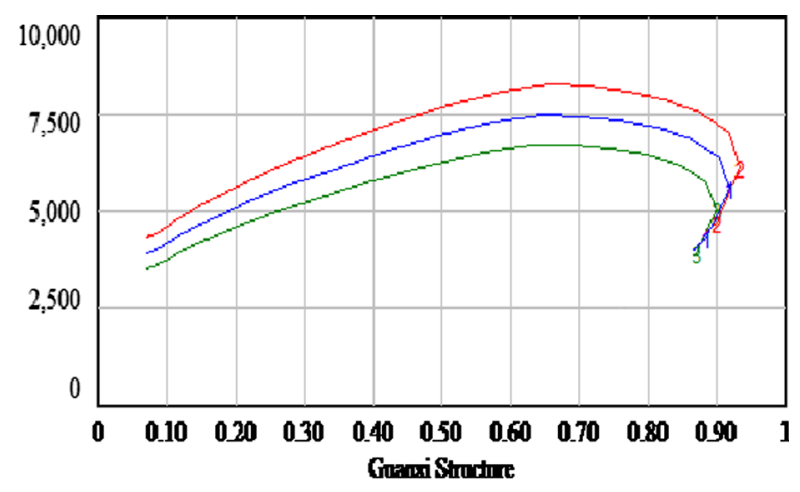

Ssles Based on Guani: current 1

S:les Based on Guami: TRANSFORMATION RATE-hith $\begin{array}{lllll}2 & 2 & 2 & 2\end{array}$

Sales Mased on Granx: :TRANSFORMATION RATK-

Fig. 26 Sensitivity analysis between guanxi structure and transformation rate

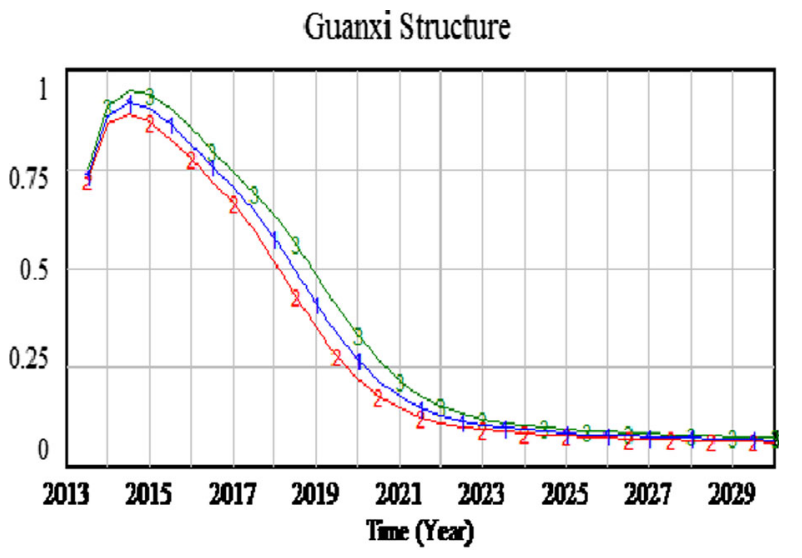

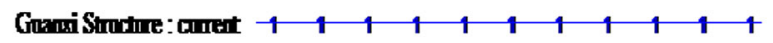

Garni Shutue:DICAY RATK-High $\begin{array}{llllllll}2 & 2 & 2 & 2 & 2 & 2 & 2 & 2\end{array}$

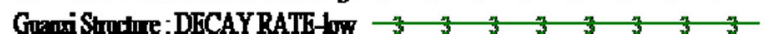

Fig. 27 Sensitivity analysis of the correlation between sales based on guanxi and guanxi structure on decay rate 


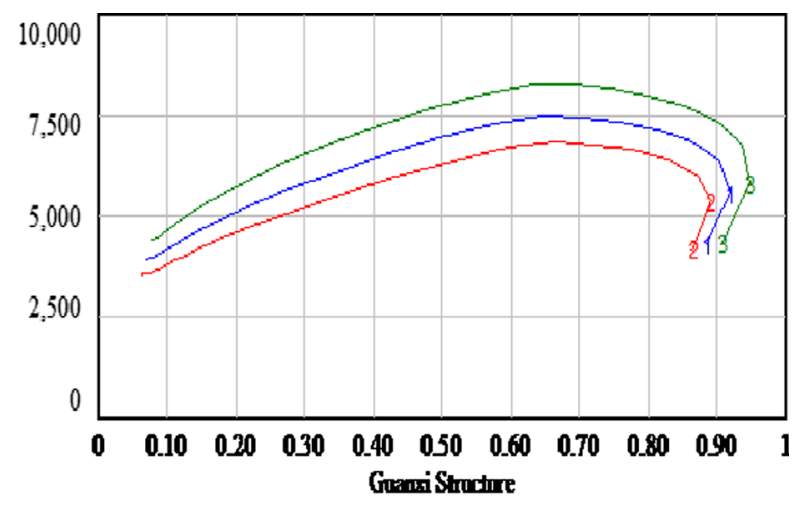

Siles Based on Grani: Curert $1 \begin{array}{cccccccccc}1 & 1 & 1 & 1 & 1 & 1 & 1 & 1 & 1 & 1\end{array}$

Sales Based on Guani:DFCAY RATE-hith $\begin{array}{llllllll}2 & 2 & 2 & 2 & 2 & 2\end{array}$

Siles Based on Gmaxi : DICCAY RATT-1m $\begin{array}{llllllll}3 & 3 & 3 & 3 & 3 & 3 & 3\end{array}$

Fig. 28 Sensitivity analysis between guanxi structure and decay rate

Guanxi Structure

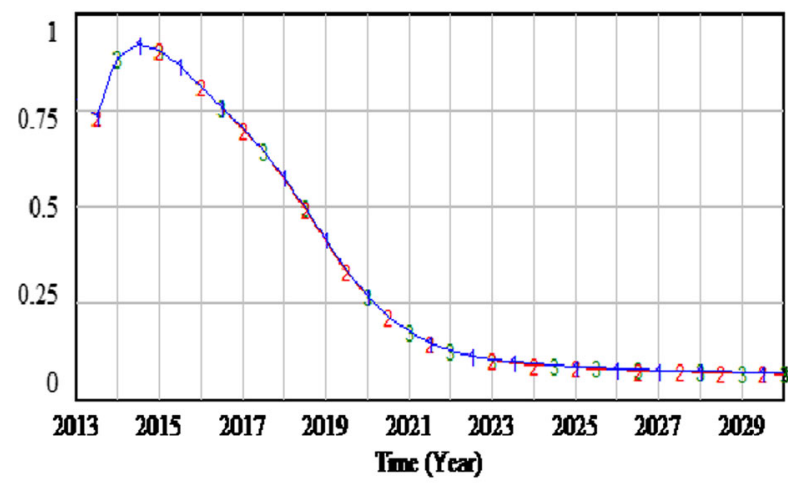

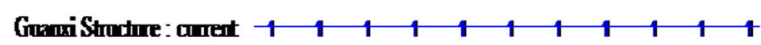

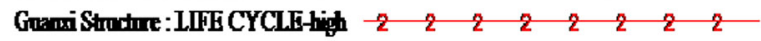

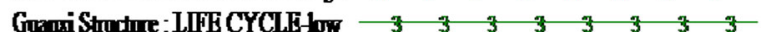

Fig. 29 Sensitivity analysis between guanxi structure and life cycle 


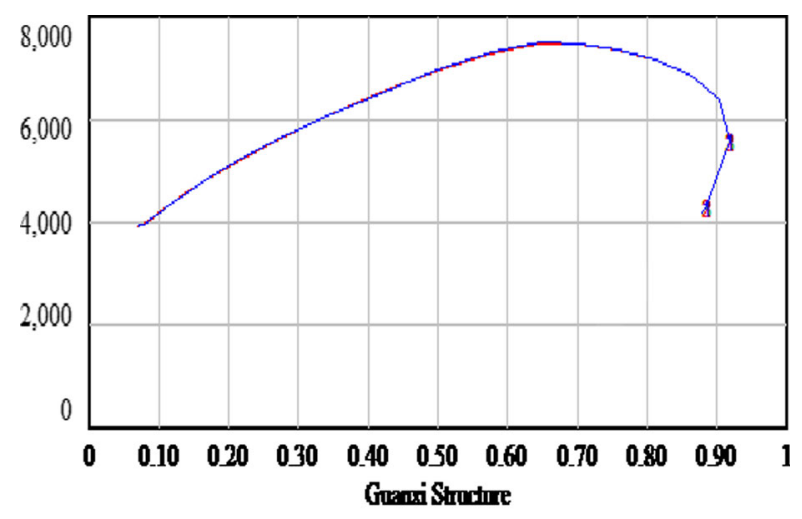

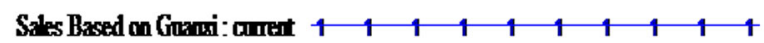
Sales Based on Grani: LIFE CYCLE high $\begin{array}{lllllll}2 & 2 & 2 & 2 & 2 & 2 & 2\end{array}$

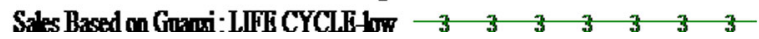

Fig. 30 Sensitivity analysis of the correlation between sales based on guanxi and guanxi structure on life cycle

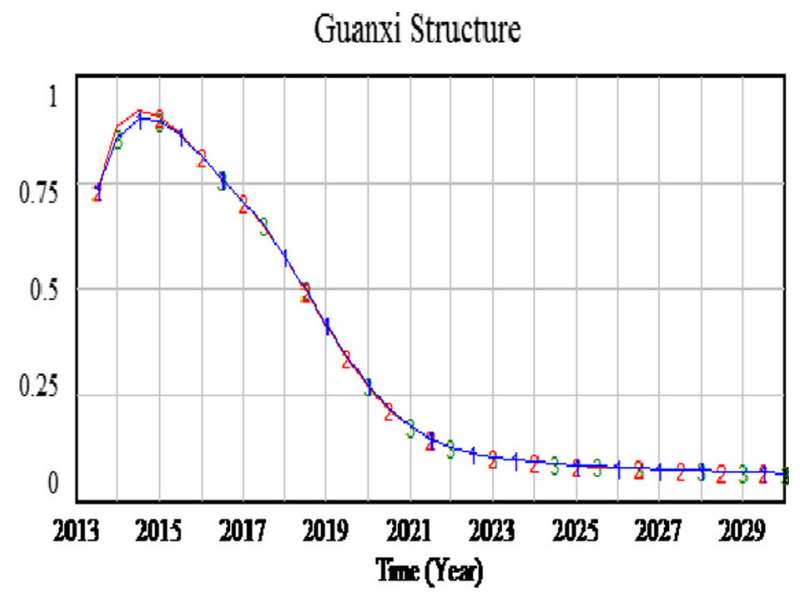

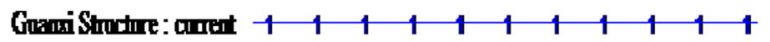

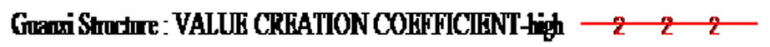

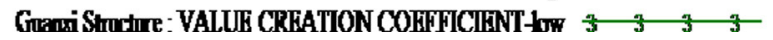

Fig. 31 Sensitivity analysis between guanxi structure and value creation coefficent 


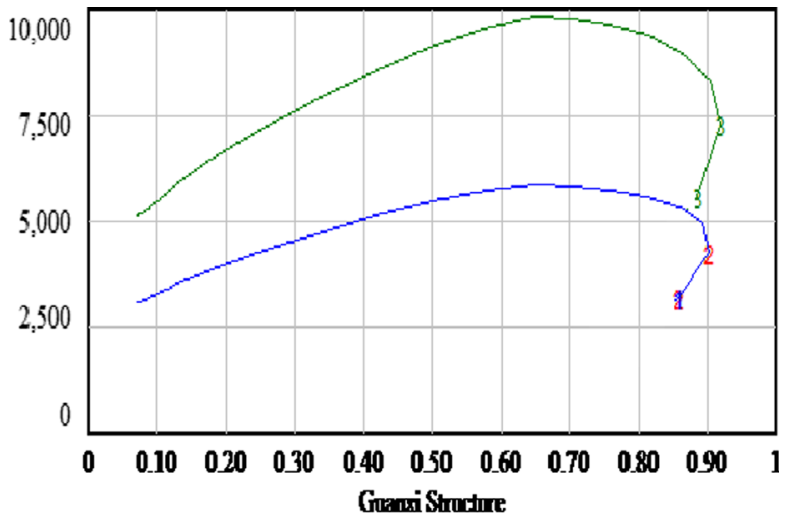

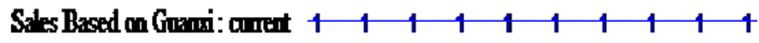

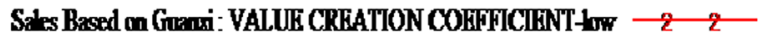

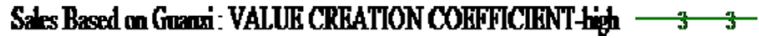

Fig. 32 S Sensitivity analysis of the correlation between sales based on guanxi and guanxi structure on value creation coefficient

\section{References}

Adler, P. S., \& Kwon, S. (2002). Social capital: prospects for a new concept. Academy of Management Review, 27, $17-40$.

Alcott, T., \& Christopoulos, C. D. (2011). Is it important to know Jack? Using social network analysis to assess regional business connectivity in Bristol. Procedia - Social and Behavioral Sciences, 10, 90-97.

Anderson, C. (2004). Free: The past and future of a radical price. New York: Hyperion Books.

Arregle, J. L., Batjargal, B., Hitt, M. A., Webb, J. W., Miller, T., \& Tsui, A. S. (2013). Family ties in entrepreneurs' social networks and new venture growth. Entrepreneurship Theory and Practice, n/a-n/a.

Arribas, I., Hernandez, P., \& Vila, J. E. (2012). Guanxi, performance and innovation in entrepreneurial service projects, No 0612. Discussion in: Papers in Economic Behaviour, University of Valencia, ERI-CES.

Batjargal, B., \& Liu M. M. (2002). Entrepreneurs' access to private equity in China: the role of social capital. Working Paper, William Davidson.

Boso, N., Story, V. M., \& Cadogan, J. W. (2013). Entrepreneurial orientation, market orientation, network ties, and performance: study of entrepreneurial firms in a developing economy. Journal of Business Venturing, $28,708-727$

Bruderl, J., \& Preisendorfre, P. (1998). Network support and the success of newly founded businesses. Small Business Economics, 10, 213-225.

Caliendo, M., Fossen, F., \& Kritikos, A. (2012). Trust, positive reciprocity, and negative reciprocity: do these traits impact entrepreneurial dynamics? Journal of Economic Psychology, 33, $394-409$.

Cantner, U., \& Graf, H. (2006). The network of innovators in Jena: an application of social network analysis. Research Policy, 35, 463-480.

Casciaro, T. (1998). Seeing things clearly: social structure, personality, and accuracy in social network perception. Social Networks, 20(4), 331-351.

Chen, Y. (2011). A study on the role of guanxi in entrepreneurship and employment. Economic Modelling, 28, 2049-2053.

Chen, Z. Y., Huang, Y., \& Sternquist, B. (2011). Guanxi practice and Chinese buyer-supplier relationships: the buyer's perspective. Industrial Marketing Management, 40, 569-580. 
Davidsson, P., \& Honig, B. (2003). The role of social and human capital among nascent entrepreneurs. Journal of Business Venturing, 18, 301-331.

De Clercq, D., Danis, W. M., \& Dakhli, M. (2010). The moderating effect of institutional context on the relationship between associational activity and new business activity in emerging economies. International Business Review, 19(1), 85-101.

Du, J., Guariglia, A. \& Newman, A. (2013). Do Social Capital Building Strategies Influence the Financing Behavior of Chinese Private Small and Medium-Sized, Entrepreneurship Theory and Practice, n/a-n/a.

Eberlein, R. L., \& Peterson, D. W. (1992). Understanding models with Vensim ${ }^{\mathrm{TM}}$. European Journal of Operational Research, 59(1), 216-219.

Evald, M. R., \& Bager, T. (2008). Managing venture team relationships in corporate incubators: a case study of network dynamics and political rivalry in a high-tech incubator. International Entrepreneurship and Management Journal, 4(3), 349-364.

Ferriani, S., Cattani, G., \& Baden-Fuller, C. (2009). The relational antecedents of project-entrepreneurship: network centrality, team composition and project performance. Research Policy, 38(10), 1545-1558.

Freeman, J., Larsen, E. R., \& Lomiy, A. (2011). Why is there no cannery in 'Cannery Row'? Exploring a behavioral simulation model of population extinction. Industrial and Corporate Change, 21, 99-125.

Fuller, T., \& Warren, L. (2006). Entrepreneurship as foresight: a complex social network perspective on organisational foresight. Futures, 38, 956-971.

Galambos, L., \& Sturchio, J. (1996). The pharmaceutical industry in the twentieth century: a reappraisal of the sources of innovation. History and Technology, 13, 83-100.

Gibb, A., \& Li, J. (2003). Organizing for company in China: what can we learn from the Chinese micro, small and medium company development experience. Futures, 35, 403-421.

Granovetter, M. S. (1973). The strength of weak ties. The American Journal of Sociology, 78(6), 1360-1380.

Granovetter, M. (1985). Economic action and social structure: the problem of embeddedness. American Journal of Sociology, 91, 481-510.

Guo, C., \& Miller, J. K. (2010). Guanxi dynamics and entrepreneurial firm creation and development in China. Management and Organization Review, 6, 267-291.

Hansen, E. L. (1995). Entrepreneurial Networks and New Organization Growth. Entrepreneurship: theory \& Practice, 19(4), 7-19.

Haggerty, J., \& Haggerty, S. (2011). The life cycle of a metropolitan business network: liverpool 1750-1810. Explorations in Economic History, 48, 189-206.

Henderson, R., Orsenigo, L., \& Pisano, G. P. (1999). The pharmaceutical industry and the revolution in molecular biology: Exploring the interactions between scientific institutional and organizational change. In D. C. Mowery \& R. R. Nelson (Eds.), The sources of industrial leadership. Cambridge: Cambridge University Press.

Hite, J., \& Hesterly, W. (2001). The evolution of firm networks: from emergence to early growth of the firm. Strategic Management Journal, 22, 275-286.

Jeon, C., \& Shin, J. (2014). Long-term renewable energy technology valuation using system dynamics and Monte Carlo simulation: photovoltaic technology case. Energy, 66, 447-457.

Karra, N., Tracey, P., \& Phillips, N. (2006). Altruism and agency in the family firm: exploring the role of family, kinship, and ethnicity. Entrepreneurship: Theory and Practice, 30, 861-877.

Kelley, D., Coner, J. K., \& Lyles, M. A. (2013). Chinese foreign direct investment in the United States: location choice determinants and strategic implications for the State of Indiana. Business Horizons, 56(4), 443-451.

Klyver, K., Hindle, K., \& Meyer, D. (2008). Influence of social network structure on entrepreneurship participation-A study of 20 national cultures. International Entrepreneurship and Management Journal, 4(3), 331-347.

Kotha, R., \& George, G. (2012). Friends, family, or fools: entrepreneur experience and its implications for equity distribution and resource mobilization. Journal of Business Venturing, 27, 525-543.

Kreiser, P. M. (2011). Entrepreneurial orientation and organizational learning: the impact of network range and network closure. Entrepreneurship: Theory and Practice, 35(5), 1025-1050.

Kreiser, P. M., Patel, P. C., \& Fiet, J. O. (2013). The Influence of changes in social capital on firm-founding activities. Entrepreneurship: Theory and Practice, 37, 539-568.

Lau, C.-M., \& Bruton, G. D. (2011). Strategic orientations and strategies of high technology ventures in two transition economies. Journal of World Business, 46, 371-380.

Lechner, C., Dowling, M., \& Welpe, L. (2006). Firm networks and firm development: the role of the relational mix. Journal of Business Venturing, 21, 514-540.

Lee, D. Y., \& Tsang, E. W. K. (2001). The effects of entrepreneurial personality, background and network activities on venture growth. Journal of Management Studies, 38(4), 583-602. 
Lerner, M., Brush, C., \& Hisrich, R. (1997). Israeli women entrepreneurs: an examination of factors affecting performance. Journal of Business Venturing, 12, 315-339.

Leung, A., Zhang, J., Wong, P. K., \& Foo, M. D. (2006). The use of networks in human resource acquisition for entrepreneurial firms: multiple "fit" considerations. Journal of Business Venturing, 21, 664-686.

Liao, D., \& Sohmen, P. (2001). The development of modern entrepreneurship in China. Stanford Journal of East Asian Affairs, 1, 27-33.

Liao, J., \& Welsch, H. (2003). Social capital and entrepreneurial growth aspiration: comparison of technologyand non-technology-based nascent entrepreneurs. The Journal of High Technology Management Research, 14, 149-170.

Li, J. J. and S. Sheng (2011). When does guanxi bolster or damage firm profitability? The contingent effects of firm- and market-level characteristics. Industrial Marketing Management, 40(4), 561-568.

Lin, N. (1999). Building a network theory of social capital. Connections, 22, 28-51.

Lockett, A., Ucbasaran, D., \& Butler, J. (2006). Opening up the investor-investee dyad: syndicates, teams, and networks. Entrepreneurship: Theory and Practice, 30, 117-130.

Lovett, S., Simmons, L. C., \& Kali, R. (1999). Guanxi versus market: ethics and efficiency. Journal of International Business Studies, 30, 231-248.

McNally, C. A. (2011). China's changing Guanxi capitalism: private entrepreneurs between Leninist control and relentless accumulation. Business and Politics, 13, 1-31.

Minniti, M. (2005). Entrepreneurship and network externalities. Journal of Economic Behavior \& Organization, 57, 1-27.

Orsenigo, L., Pammolli, F., \& Riccaboni, M. (2001). Technological change and network dynamics lessons from the pharmaceutical industry. Research Policy, 30, 485-508.

Park, S. H., \& Luo, Y. (2001). Guanxi and organizational dynamics: organizational networking in Chinese firms. Strategic Management Journal, 22(5), 455-477.

Parker, S. C. (2008). The economics of formal business networks. Journal of Business Venturing, 23, 627640.

Patel, P. C., \& Terjesen, S. (2011). Complementary effects of network range and tie strength in enhancing transnational venture performance. Strategic Entrepreneurship Journal, 5(1), 58-80.

Peng, M. W. (2003). Institutional transitions and strategic choices. Academy of Management Review, 28, 275296.

Pitt, L., Merwe, R. V. D., Berthon, P., Salehi-Sangari, E., \& Barnes, B. R. (2006). Swedish biotech SMEs: the veiled values in online networks. Technovation, 26, 553-560.

Powell, W. W. (1996). Interorganizational collaboration in the bio-technology industry. Journal of Institutional and Theoretical Economics, 152, 197-215.

Powell, W. W., Doput, K. W., \& Smith-Doerr, L. (1996). Interorganizational collaboration and the locus of innovation: networks of learning in biotechnology. Administrative Science Quarterly, 41, 116-145.

Puffer, S. M., McCarthy, D. J., \& Boisot, M. (2010). Entrepreneurship in Russia and China: the impact of formal institutional voids. Entrepreneurship: Theory and Practice, 34, 441-467.

Pun, K. F., Chin, K. S., \& Lau, H. (2000). A review of the Chinese cultural influences on China's company management. International Journal of Management Reviews, 2, 325-338.

Rosenkopf, L., \& Schilling, M. A. (2007). Comparing alliance network structure across industries: observations and explanations. Strategic Entrepreneurship Journal, 1, 191-209.

Schulze, W. (2007). Networks and strategic entrepreneurship: comments on comparing alliance network structure across industries: observations and explanations and entrepreneurial ventures. Strategic Entrepreneurship Journal, 1, 229-231.

Schutjens, V., \& Stam, E. (2003). The evolution and nature of young firm networks: a longitudinal perspective. Small Business Economics, 21, 115-134.

Semrau, T., \& Werner, A. (2013). How exactly do network relationships pay off? The effects of network size and relationship quality on access to start-up resources. Entrepreneurship Theory and Practice. doi:10. 1111/etap.12011.

Shah, N. (2004). Pharmaceutical supply chains: key issues and strategies for optimization. Computers \& Chemical Engineering, 28, 929-941.

Sheng, S., Zhou, K. Z., \& Li, J. J. (2011). The effects of business and political ties on firm performance: evidence from China. Journal of Marketing, 75, 1-15.

Stam, W., \& Elfring, T. (2006). Entrepreneurial orientation and new venture performance: The mediating effect of network strategies. The Academy of Management Best Paper Proceedings [ENT Division], Atlanta.

Staropoli, C. (1998). Cooperation in R\&D in the pharmaceutical industry - the network as an organizational innovation governing technological innovation. Technovation, 18, 13-23. 
Stearns, T. M. (1996). Strategic alliances and performance of high technology new firms. Frontiers of Entrepreneurship Research, 7(2), 268-281.

System Dynamics Society. (2013). The field of system dynamics. http:/www.Systemdynamics.org/what-is-s/.

Theingi, S. P., \& Phungphol, Y. (2008). Social capital in Southeast Asian business relationships. Industrial Marketing Management, 37, 523-530.

Troilo, M., \& Zhang, J. (2012). Guanxi and entrepreneurship in urban China. Journal of the Asia Pacific Economy, 17, 315-331.

Ucbasaran, D., Lockett, A., Wright, M., \& Westhead, P. (2003). Entrepreneurial founder teams: factors associated with member entry and exit. Entrepreneurship: Theory and Practice, 28, 107-127.

Walker, G., Kogut, B., \& Shan, W. (1997). Social capital, structural holes and the formation of an industry network. Organization Science, 8, 105-125.

Wang, K., Hong, J., Marinova, D., \& Zhu, L. (2009). Evolution and governance of the biotechnology and pharmaceutical industry of China. Mathematics and Computers in Simulation, 79, 2947-2956.

Webb, J. W., Kistruck, G. M., Ireland, R. D., \& Ketchen, J. D. J. (2010). The entrepreneurship process in base of the pyramid markets: the case of multinational enterprise/nongovernment organization alliances. Entrepreneurship: Theory and Practice, 34, 555-581.

Weber, C., \& Weber, B. (2011). Exploring the antecedents of social liabilities in CVC triads - a dynamic social network perspective. Journal of Business Venturing, 26, 255-272.

Wright, M., Liu, X., Buck. T., \& Filatotchev, I. (2008) Returnee entrepreneurs, science park location choice and performance: an analysis of high-technology SMEs in China. Entrepreneurship Theory and Practice, 32(1), 131-155.

Xavier, S. R., Kelley, D., Kew, J., Herrington, M., Vorderwülbecke, A., \& GERA. (2013) GEM 2012 Global Report, http://www.gemconsortium.org.

Xin, K. R., \& Pearce, J. L. (1996). Guanxi: connections as substitutes for formal institutional support. Academy of Management Journal, 39, 1641-1658.

Yang, H., \& Jiang, Y. (2010). Research on the relation between GUANXI culture and the stability of entrepreneurial supply chain. IEEE, 21(2), 1348-1352.

Yang, Z., \& Wang, C. L. (2011). Guanxi as a governance mechanism in business markets: its characteristics, relevant theories, and future research directions. Industrial Marketing Management, 40, 492-495.

Yang, H. \& J. Tang (2004). Team structure and team performance in IS development: a social network perspective. Information \& Management, 335-349.

Yeung, I. Y., \& Tung, R. L. (1996). Achieving business success in Confucian societies: the importance of guanxi. Organizational Dynamics, 3, 54-65.

Yu, J., Zhou, J. X., Wang, Y., \& Xi, Y. (2013). Rural entrepreneurship in an emerging economy: reading institutional perspectives from entrepreneur stories. Journal of Small Business Management, 51, 183-195.

Zhang, H., Amodio, J. C., \& Haapala, K. R. (2013). A conceptual model for assisting sustainable manufacturing through system dynamics. Journal of Manufacturing Systems, 32, 543-549.

Zhang, Z., Lu, W. X., Zhao, Y., \& Song, W. B. (2014). Development tendency analysis and evaluation of the water ecological carrying capacity in the Siping area of Jilin Province in China based on system dynamics and analytic hierarchy process. Ecological Modelling, 275, 9-21.

Zolin, R., Kuckertz, A., \& Kautonen, T. (2011). Human resource flexibility and strong ties in entrepreneurial teams. Journal of Business Research, 64, 1097-1103. 